\title{
Impact of dust aerosols on the radiative budget, surface heat fluxes, heating rate profiles and convective activity over West Africa during March 2006
}

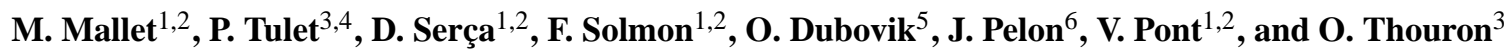 \\ ${ }^{1}$ Université de Toulouse, UPS; LA (Laboratoire d'Aérologie), 14 avenue Edouard Belin, 31400 Toulouse, France \\ ${ }^{2}$ CNRS, LA (Laboratoire d'Aérologie), 31400 Toulouse, France \\ ${ }^{3}$ CNRM/GAME, METEO-France, 42 av G. Coriolis, 31047, Toulouse, France \\ ${ }^{4}$ LACy, Université de La Réunion, 15 avenue René Cassin, 97715 Saint-Denis, France \\ ${ }^{5}$ Laboratoire d'Optique de l'Atmosphère, Université des Sciences et Technologies de Lille, CNRS, Villeneuve d'Ascq, France \\ ${ }^{6}$ LATMOS, Institut Pierre Simon Laplace, Paris, France
}

Received: 6 November 2008 - Published in Atmos. Chem. Phys. Discuss.: 29 January 2009

Revised: 28 April 2009 - Accepted: 10 September 2009 - Published: 24 September 2009

\begin{abstract}
The present work analyses the effect of dust aerosols on the surface and top of atmosphere radiative budget, surface temperature, sensible heat fluxes, atmospheric heating rate and convective activity over West Africa. The study is focused on the regional impact of a major dust event over the period of 7-14 March 2006 through numerical simulations performed with the mesoscale, nonhydrostatic atmospheric model MesoNH. Due to its importance on radiative budgets, a specific attention has been paid to the representation of dust single scattering albedo (SSA) in MesoNH by using inversions of the AErosol RObotic NETwork (AERONET). The radiative impacts are estimated using two parallel simulations, one including radiative effects of dust and the other without them. The simulations of dust aerosol impacts on the radiative budget indicate remarkable instantaneous (at midday) decrease of surface shortwave $(\mathrm{SW})$ radiations over land, with regional $\left(9^{\circ}-17^{\circ} \mathrm{N}, 10^{\circ} \mathrm{W}-\right.$ $20^{\circ} \mathrm{E}$ ) mean of $-137 \mathrm{~W} / \mathrm{m}^{2}$ during the 9 to 12 March period. The surface dimming resulting from the presence of dust is shown to cause important reduction of both surface temperature (up to $4^{\circ} \mathrm{C}$ ) and sensible heat fluxes (up to $100 \mathrm{~W} / \mathrm{m}^{2}$ ), which is consistent with experimental observations. At the top of the atmosphere, the SW cooling (regional mean of $-12.0 \mathrm{~W} / \mathrm{m}^{2}$ ) induced by mineral dust is shown to dominate the total net (shortwave+longwave) effect. The maximum
\end{abstract}

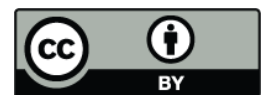

Correspondence to: $\mathrm{M}$. Mallet (malm@aero.obs-mip.fr)
SW heating occurs within the dusty layer with values comprised between 4 and $7^{\circ} \mathrm{K}$ by day and LW effect results in a cooling of $-0.10 /-0.20^{\circ} \mathrm{K}$ by day. Finally, the simulations suggest the decrease of the convective available potential energy (CAPE) over the region in the presence of mineral dust.

\section{Introduction}

Numerous studies have been dealing with estimation of direct effects associated with major aerosol types (urban/industrial, smoke and mineral dust) and related changes of the radiative budget at the surface, top of atmosphere (TOA) and within the aerosol layer. Such studies (Tegen and Lancis, 1996; Myhre and Stordahl, 2001; Lelieveld et al., 2002; Huebert et al., 2003; Tanré et al., 2003; Abel et al., 2005; Ramanathan et al., 2007; Haywood et al., 2008; Heinold et al., 2009; Bierwirth et al., 2009; Otto et al., 2009) underline that fine aerosols (urban/industrial and/or smoke particles) decrease significantly surface incoming shortwave radiations and generally increase (or rarely decrease in some specific cases; Haywood and Shine, 1995) outgoing shortwave fluxes reflected back to space. Except in cases of pure scattering particles, the net effect for the atmosphere is positive revealing a gain of solar energy within the aerosol layer. The effect of dust particles is more complex because of their ability to interact both in shortwave and longwave radiations. As a result, top of the atmosphere SW and LW forcings are

Published by Copernicus Publications on behalf of the European Geosciences Union. 
generally opposite: the presence of the dust generally increases (except above high surface albedo) upward fluxes in shortwave and decreases them in longwave spectral range.

Over a given region, these various radiative effects, occurring at different atmospheric levels (surface, TOA and within the aerosol layer), all contribute to the climatic response. Thus it is very important to understand how these forcings can act together and alter the surface energy budget (heat fluxes), cloud properties (semi-direct effect), atmospheric dynamics as well as hydrological cycle (modification of precipitation regimes). For example, the studies conducted during the INDOEX experiment (Ramanathan et al., 2001) over the Indo-Asian region reveal that surface cooling and troposheric heating associated with particles are able to significantly perturb the regional climate and tropical rainfall patterns with implications for global climate (Ramanathan et al., 2001). In parallel, different studies based on regional and global climate models suggest significant effects of dust aerosols on the West African monsoon (WAM) development and Sahelian precipitation (Miller and Tegen, 1998; Miller et al., 2004; Lau and Kim, 2006; Yoshioka et al., 2007; Konaré et al., 2008; Solmon et al., 2008).

West Africa is subject to large smoke and mineral dust loadings able to significantly modify the regional radiative budget. Indeed, the Sahara desert acts as the strongest source of mineral dust aerosol in the world (Woodward, 2001; Prospero et al., 2003). The most intense dust events in Sahara and Sahelian regions are frequently generated in summer (Marticorena et al., 1997) due to favourable large scale conditions, but there is also a significant dust production throughout the year. In addition, the burning of agricultural waste in the Sahelian region during the dry season makes of West Africa one of the strongest source of biomass burning aerosols.

Presently, the potential impact of dust and smoke particles on the West Africa climate is unclear and the estimation of this impact is one of the main purposes of the AMMA (African Monsoon Multidisciplinary Analysis) program (Redelsperger et al., 2006), a major international campaign investigating different aspects of the African monsoon (climate dynamics, hydrological cycle, aerosol/chemistry and impacts). Ground-based measurements, coupled with aircraft and satellite observations of aerosols have been developed within the AMMA program for investigating their influence on the radiation balance of the earth/atmosphere system.

The present study investigates the direct radiative forcing of mineral dust and its potential impact in terms of change in surface temperature and sensible heat fluxes, heating rate profiles and atmospheric dynamic. This work has been conducted by using the MesoNH meso-scale forecasting model (Lafore et al., 1998) fully coupled with a dust production and transport model (Grini et al., 2006), a radiation scheme and an explicit land surface model. This kind of "on-line" model enables to investigate how the aerosols direct radiative forcing impact the surface-atmosphere system. Due to the significant impact of dust SSA on the radiative budget (both at TOA, surface SRF, and into the dust layer) and heating rate profiles, we used dust refractive indexes retrieved by AERONET (Dubovik and King, 2000) together with the size distribution for calculating the shortwave dust SSA used in our MesoNH simulations. In parallel, experimental observations obtained at Djougou (Northern Benin) allowed to complement modelling simulations. Here, we perform a case study for an intense dust event occurring during March 2006 (Slingo et al., 2006; Milton et al., 2008; Tulet et al., 2008; McFarlane et al., 2009), leading to dust aerosol optical depth (AOD) larger than 2 (at $550 \mathrm{~nm}$ ) over a large part of West Africa.

Simulations begin at 00:00 UTC on 7 March 2006, and end at 00:00 UTC on 14 March 2006. The large domain used $\left(12 \times 12 \mathrm{~km}\right.$ resolution) between $3.1^{\circ} \mathrm{S}$ and $31.7^{\circ} \mathrm{N}$ in latitude and $25.64^{\circ} \mathrm{W}$ and $35.64^{\circ} \mathrm{E}$ in longitude, gives a large scale synoptic view of west Africa. The vertical resolution is composed of 60 stretched vertical levels reaching the altitude of $34000 \mathrm{~m}$, whereas 30 levels are located in the boundary layer between the surface and $2000 \mathrm{~m}$. Initialization and lateral boundary conditions of the large domain were taken from the ECMWF analysis. The dust AOD evolution (Fig. 1) simulated by MesoNH is fully described by Tulet et al. (2008).

The structure of the paper is the following. The first part (Sect. 2) describes the experimental observations performed at Djougou (Northern Benin), especially in terms of surface sensible fluxes. Section 3 presents the developments of the dust optical properties in MesoNH. Finally, the impact of dust aerosols on the radiative budget, surface heat fluxes, heating rate profiles as well as convective activity is discussed in the Sect. 4. The conclusions and summary of this work are given in the Sect. 5.

\section{Data analysis of sensible heat fluxes}

Associated with ground-based observations of microphysical, chemical and optical properties of aerosols (Pelon et al., 2008; Mallet et al., 2008), experimental measurements of surface sensible heat fluxes $(\mathrm{H})$ were conducted at Djougou. Here, we just detail the methodology used for estimating surface fluxes, based on the eddy covariance method, which is considered as the reference method for vertical flux scalar measurement (Beverland et al., 1996).

This method is based on the direct high frequency measurement of the two components of the vertical flux of a scalar: the vertical wind speed " $w$ " and the scalar itself, " $c$ " here, which can be temperature, water vapor mixing ratio or $\mathrm{CO}_{2}$ concentration. Flux comes as the integral of the product of the vertical wind speed fluctuation $w^{\prime}$ and of the scalar $c^{\prime}$ :

$\mathrm{F}_{c}=\overline{w^{\prime} c^{\prime}}=\frac{1}{T} \int_{0}^{T} w^{\prime}(t) c^{\prime}(\mathrm{t}) d t=\frac{1}{T} \mathrm{f}(\mathrm{t})$ with $\mathrm{f}(\mathrm{t})$ 

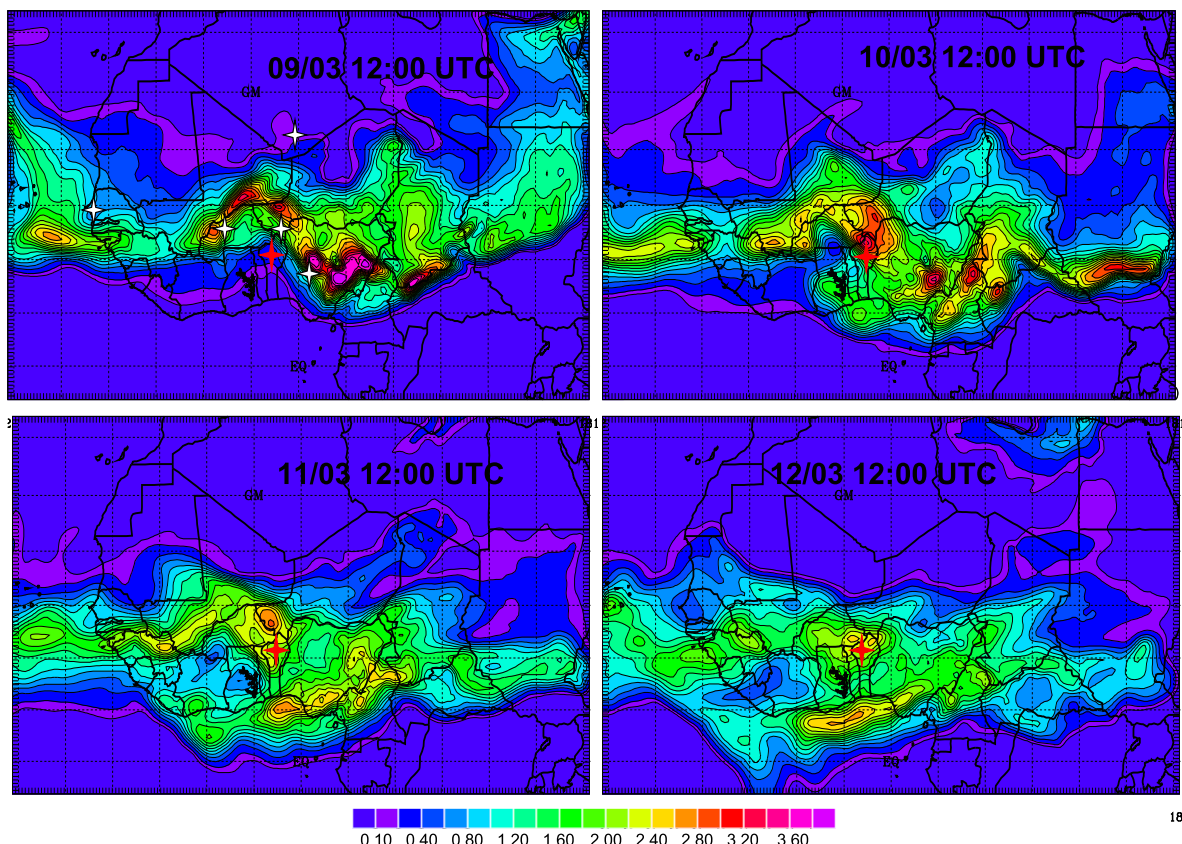

Fig. 1. DOD (at $560 \mathrm{~nm}$ ) simulated at noon by MesoNH for the 9 (left up), 10 (right up), 11 (left down) and 12 March (right down) 2006. The different stars represent the AERONET/PHOTONS sites. The red one corresponds to the Djougou (Benin) site.

$=\int_{0}^{T} w^{\prime}(\mathrm{t}) c^{\prime}(\mathrm{t}) d t$

Although this method presents a number of advantages, the processing of raw data shows that data control is necessary to guarantee their quality for further use (Foken et al., 1996; Affre et al., 2000). Such a control is relatively simple since all the turbulence functions involved are available and can be verified at all post-treatment steps.

Turbulence stationary is one of the fundamental hypotheses that should be fulfilled when determining turbulent fluxes. The presence of low frequencies, which usually are not of local turbulent origin, but can be induced by the constraint of large-cell circulations or meso-scale events in the Atmospheric Boundary Layer (ABL), implies longer scale processes in the turbulent fluctuations. They can yield significant disturbances in flux evaluation. For this reason, and as defined in Affre et al. (2000), the contribution to $w^{\prime} c^{\prime}$ covariance is studied along the sample. The evolution of the integral function $\mathrm{f}(\mathrm{t})$ defined in Eq. (1) is a indication of the quality of the integral flux which is given by $(\mathrm{f}(T)-\mathrm{f}(0)) / T$. There is a second way for calculating the flux which is based on a statistical approach. In that case, the flux is no more calculated on the integral slope, but on the statistical slope deducted from the least mean squares.

Sensible, latent heat and $\mathrm{CO}_{2}$ fluxes were measured together with the Eddy Correlation (EC) technique for a period extending from 1 September 2005 to 6 April 2007. Experimental set up included a Gill ${ }^{\circledR}$ R1 3D sonic anemometer, a Licor ${ }^{\circledR} 7500$ open path Infrared Gas analyzer, and a labmade datalogger. $8 \mathrm{~Hz}$ logging of horizontal wind components $(U, V)$, vertical wind component $(W)$, temperature $(T), \mathrm{H}_{2} \mathrm{O}$ and $\mathrm{CO}_{2}$ data was performed on a $30 \mathrm{~min}$ basis. Sonic and Licor 7500 path were located at $8 \mathrm{~m}$ above ground level at the tip of a $2 \mathrm{~m}$ pole born by a scaffolding.

\section{Radiative effect parametrization and dust optical properties}

The MesoNH model uses the radiation code of ECMWF (Fouquart and Bonnel, 1980; Morcrette and Fouquart, 1986), which computes the radiative fluxes of solar and thermal infrared radiation. We used here the standard formulation of absorptivity/emissitivity of longwave radiation for aerosols in the ECMWF model. Scattering of longwave radiation by mineral dust is neglected in our radiative calculations. As reported by Dufresne et al. (2002), this may lead to an underestimation of longwave radiative forcing by up to $50 \%$ at TOA and $15 \%$ at the surface. It should be noted that dust optical properties are calculated in the longwave region (divided into 16 spectral bands) by using the work of Koepke et al. (1997).

Here, we discuss about the simulations of dust SSA in the shortwave region. The simulations of dust AOD were described in Tulet et al. (2008). The aerosol SSA (i.e. ratio between scattering and extinction of light) is the optical property that determines the sign of TOA forcing (Lio and Seinfeld, 1998), depending on a critical surface albedo 
$\left(R_{S, c}\right)$ (Fraser and Kaufman, 1985). As an example, for a SSA of $0.90, R_{s, c}$ is around 0.3 . As the West African continent is characterized by a significant North-South gradient of the surface albedo, a rigorous estimation of the dust SSA is necessary for well exploring the mineral dust impact at the regional scale.

The calculations of SSA requires the knowledge of the size and the complex refractive index $(m=n-i k$, where $n$ and $k$ are the real and imaginary part, respectively) of the particle. While the size distribution is usually provided by aerosol model output, the refractive indexes of the dust are usually fixed in climate simulations to the values from available databases (e.g. Koepke et al., 1997; Hess et al., 1998). However, the recent findings indicated a possibility of strong deviations of these literature values from the real ones, which are controlled by dust chemical composition (especially percentage of hematite; Lafon et al., 2006) and mixing with other primary (black carbon) and/or secondary aerosols (organics, sulphate, ...). For example, the remote sensing study of Dubovik et al. (2002) reported much lower desert dust absorption in visible spectral range than commonly used in aerosol properties databases although more recent work proposed by Sinyuk et al. (2007) seems indicating larger dust absorption close to typical model values. In that sense, difference in dust SSA could lead to substantial errors on dust radiative forcings.

Therefore, in order to take into account the most realistic dust SSA in our numerical simulations, we have used dust size distributions as simulated by MesoNH (Tulet et al., 2005; Grini et al., 2006) together with dust refractive indexes retrieved from AERONET/PHOTONS radiometers measurements (Dubovik and King, 2000) during the dust outbreak. AERONET database provides spectral optical thickness directly measured from the surface and the detailed microphysical aerosol properties including size distribution, refractive index, SSA derived from both direct sun and diffuse sky-radiances measurements using inversion algorithm by Dubovik and King (2000). Recently, this algorithm was updated with several improvements (generating Version 2 retrievals used here). First, in order to account for aerosol non-sphericity, the coarse mode of desert dust is modeled as a mixture of randomly oriented spheroids (Dubovik et al., 2006). Second, the assumed surface reflectance model accounts for reflectance directionality and based on MODIS surface reflectance climatology (Sinyuk et al., 2007; Eck et al., 2008).

Our methodology is described in the Fig. 2. Dust size distribution and AERONET refractive index have been used in Mie calculations to derive dust optical properties required for radiative forcing calculations (extinction coefficients, SSA and g). As reported by Milton et al. (2008), the assumption of spherical particles appears here reasonable. Indeed, author's performed optical calculations by using mixtures of oblate and prolate spheroids and concluded that difference in SSA and $\mathrm{g}$ are lower than $10 \%$. This result is in accordance with those reported by Mishchenko et al. (1995) and Bellouin et al. (2004).

During the dust outbreak, the mean values (and associated errors) of the refractive index (at $440 \mathrm{~nm}$ ) are about $1.45 \pm 0.04$ and $0.0029 \pm 0.0014$, for the real and imaginary parts, respectively. Figure 3 displays bulk dust SSA at $560 \mathrm{~nm}$ as obtained (at noon) over the West Africa region at the surface and $2 \mathrm{~km}$ height for the 9 and 10 March, showing SSA about 0.90-0.92 in the dust plume. Lower values are observed near sources, where the contribution of larger particles, which are more absorbing than fine dust in the SW, is maximum.

Such SSA values are found to be lower than those recently obtained over North Africa during DODO1 and DODO2 (0.99 and 0.98) (McConnell et al., 2008), DABEX during January 2006 at Niamey (0.99) (Osborne et al., 2008) and SHADE (0.97) (Haywood et al., 2003). This is due to the fact that the ORILAM scheme takes into account the coarse mode of the dust size distribution while both campaigns mentioned accounting only for the accumulation mode. McConnell et al. (2008) reported that the addition of the coarse mode induces a substantial change on SSA (at $550 \mathrm{~nm}$ ) during DODO2 from 0.98 to 0.90 , underlying that an accurate measurement of the coarse mode in mineral dust is extremely important for investigating dust radiative effects and climatic impacts.

The dust SSA spectral dependence was also rigorously included in our calculations, indicating that SSA increases with wavelengths in the dusty layer, changing from 0.88 to 0.91 (10 March), at 360 and $560 \mathrm{~nm}$, respectively. This result is quite consistent with two years (1998-2000) of AERONET observations for mineral dust over Persian Gulf and Saudi Arabia, revealing changes of dust SSA (estimated over the total atmospheric column) from 0.90 to 0.95 , at 440 and $670 \mathrm{~nm}$, respectively (Sinyuk et al., 2007).

\section{Results and discussion}

\subsection{Dust effect on surface downward radiation}

In this section, we discuss the effect of dust on surface (SRF) downward radiation, both in shortwave (SW) and longwave (LW) spectral ranges. We characterise this effect by calculating the difference at the surface:

SRF_SW $=($ SW_DOWN $)$ DUST $-($ SW_DOWN $)$ NONE

where SW_DOWN is net fluxes at the surface for dust-laden (DUST) and dust-free (NONE) cases. The same convention is used in the longwave region for calculating SRF_LW. With this convention, a negative sign of SRF_SW (or SRF_LW) implies an overall cooling effect at the surface and a positive one a heating effect. 1D sensitivity tests have been performed by taking into account uncertainties in dust SSA and $g$ and are reported in Table 1. Our calculations indicate that the 
Table 1. Error budget on the determination of the aerosol direct forcing (at the surface, SRF, and at $10 \mathrm{~km}$ height, TOA) including optical parameters of aerosols and the surface albedo (reference case : Dust Optical Depth $=0.5$ at $550 \mathrm{~nm}$, Surface albedo, Rs=0.20, Dust Single Scattering Albedo=0.90 and asymmetry parameter=0.70, thermodynamic profiles are coming from Mallet et al. (2008)). Each calculation is performed for a zenithal angle of $60^{\circ}$.

\begin{tabular}{lrr}
\hline & SRF dust forcing $\left(\mathrm{W} / \mathrm{m}^{2}\right)$ & TOA dust forcing $\left(\mathrm{W} / \mathrm{m}^{2}\right)$ \\
\hline Reference case & -100 & -32 \\
Case 1: Ref \& SSA -0.03 & $-111(+10 \%)$ & $-27(-20 \%)$ \\
Case 2: Ref \& SSA+0.03 & $-91(-9 \%)$ & $-37(+14 \%)$ \\
Case 3: Ref \& g+0.04 & $-96(-4 \%)$ & $-28(-13 \%)$ \\
Case 4: Ref \& g-0.04 & $-106(+6 \%)$ & $-35(+10 \%)$ \\
Case 5: Ref \& Rs+0.05 & $-99(-1 \%)$ & $-35(+10 \%)$ \\
Case 6: Ref \& Rs-0.05 & $-101(+1 \%)$ & $-18(-40 \%)$ \\
\hline
\end{tabular}

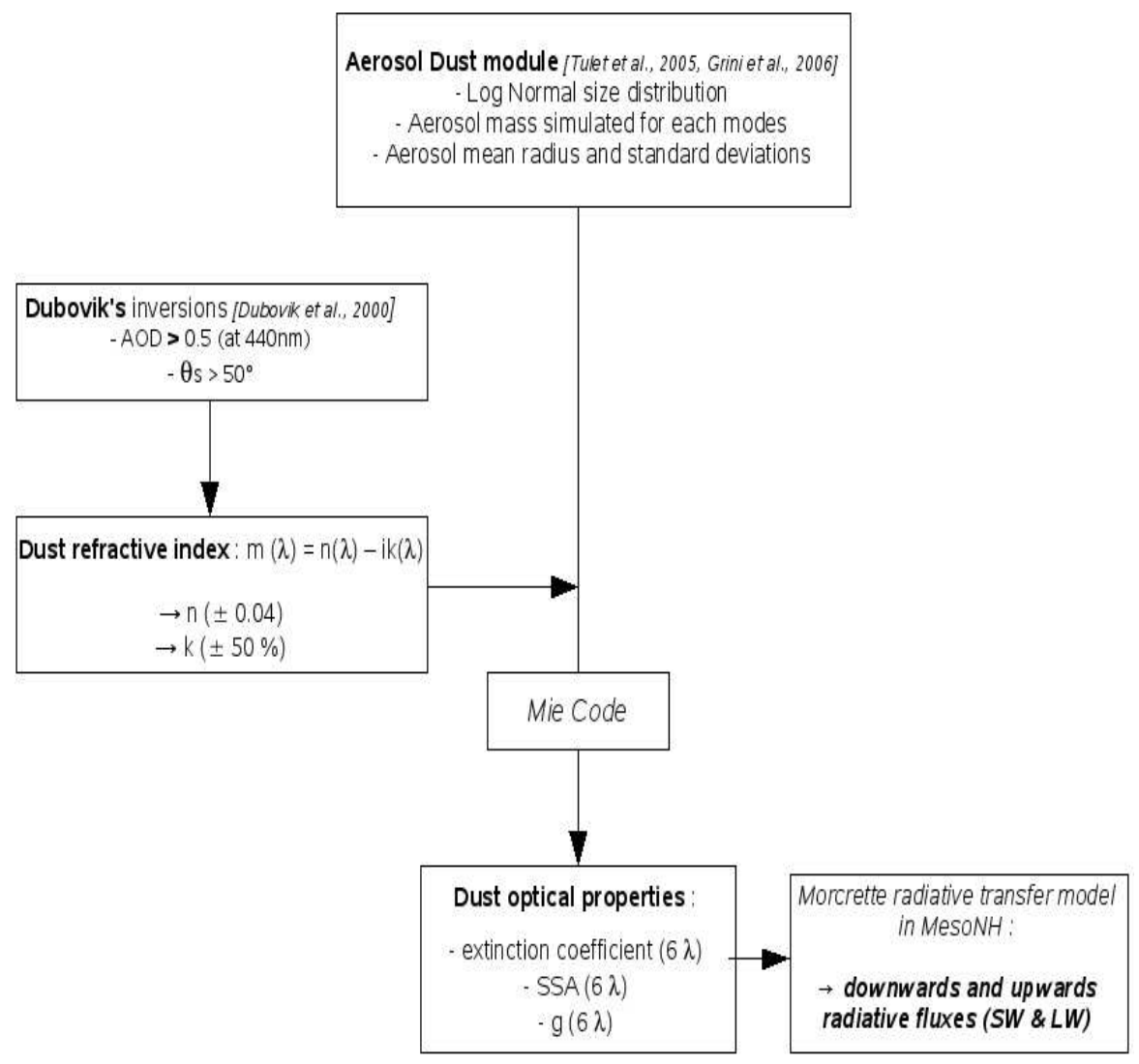

Fig. 2. Methodology developed to compute the dust direct radiative forcing in the MesoNH model by using the AERONET dust refractive index together with prescribed dust size distribution (Tulet et al., 2005) (see Sect. 3 for further details).

direct radiative effect of dust aerosols at the surface could be defined with an accuracy of $\pm 15 \%$.

\subsubsection{Solar spectral range}

Figure 4 reports the instantaneous shortwave surface effect (simulated at noon) for the 9, 10, 11 and 12 March. Results presented in the Fig. 4 clearly indicate that solar radiative fluxes are significantly reduced at the surface when the radiative effect of dust is included in MesoNH simulations. The reduction of the surface illumination is due to the reflection of solar radiations on the dusty layer but also because of absorption by mineral aerosols as dust SSA is lower than 1 (see Sect. 3). 
(Min: 0.882E+00, Max: 0.925E+00)

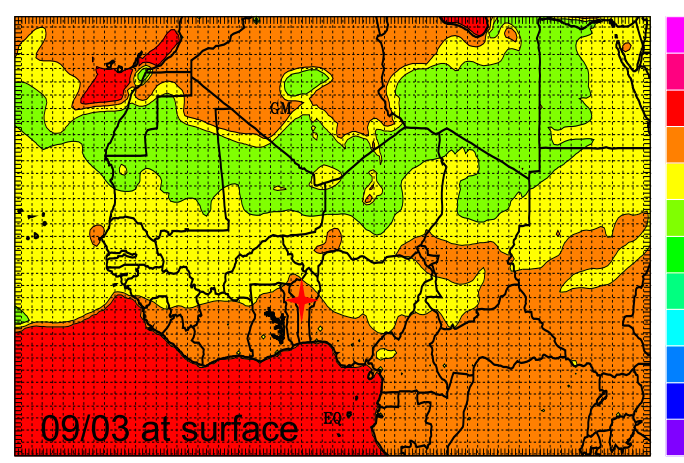

(Min: $0.867 \mathrm{E}+00, \operatorname{Max:} 0.918 \mathrm{E}+00)$

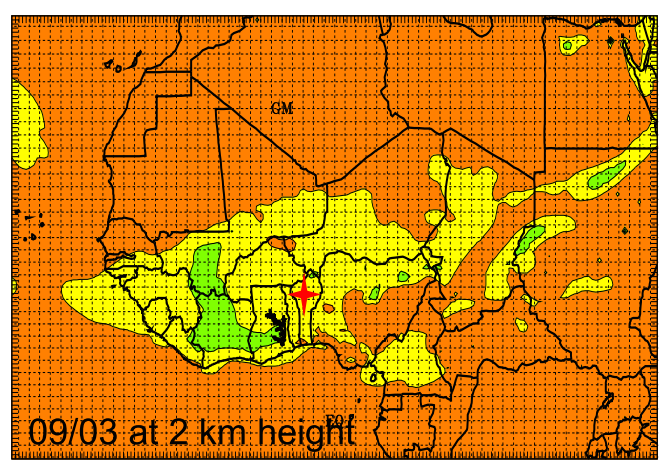

(Min: $0.848 \mathrm{E}+00$, Max: $0.925 \mathrm{E}+00)$

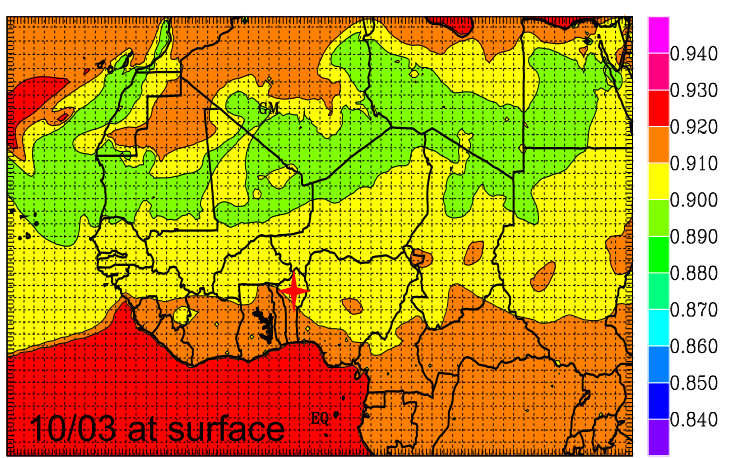

(Min: $0.863 \mathrm{E}+00, \operatorname{Max}: 0.919 \mathrm{E}+00)$

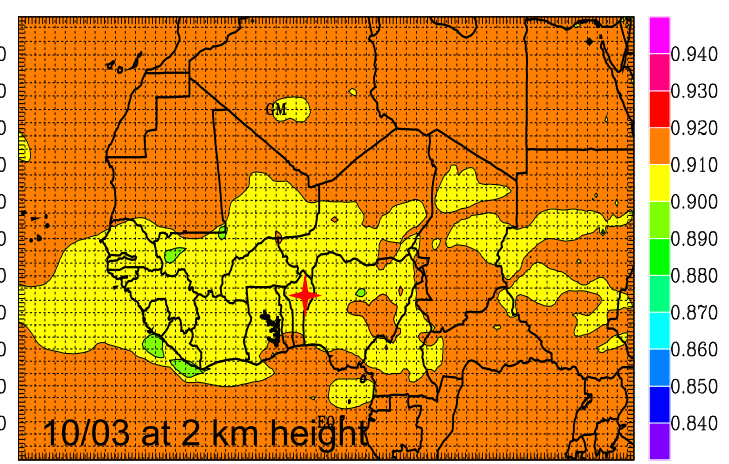

181

Fig. 3. Dust SSA (at $560 \mathrm{~nm}$ ) estimated at noon by MesoNH at the surface (bottom) and $2 \mathrm{~km}$ height (down), for the 9 (left) and 10 (right) March. The red star corresponds to the Djougou (Benin) station.
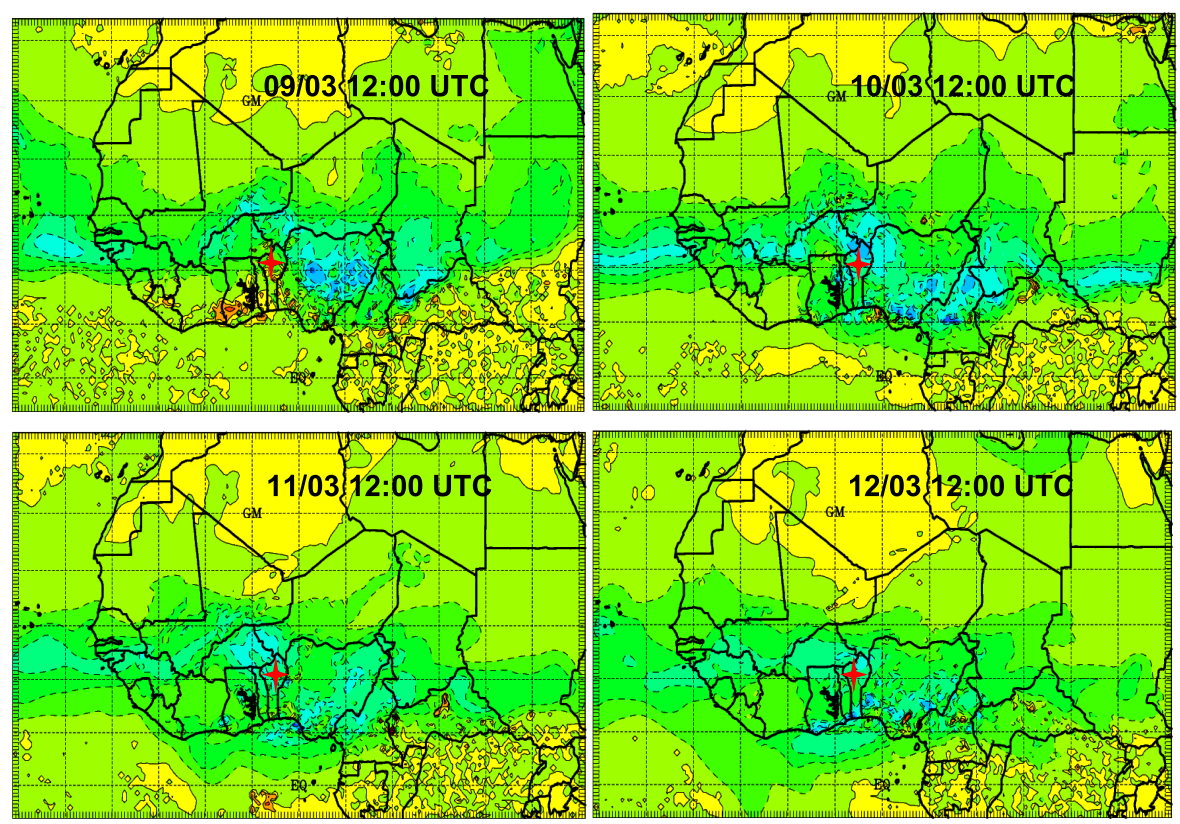

$-750-650-550-450-350-250-150-50 \quad 0 \quad 50150250350450550$

Fig. 4. Instantaneous (noon) dust radiative effect at the surface (in $\mathrm{W} / \mathrm{m}^{2}$ ) simulated by MesoNH for the 9 (left up), 10 (right up), 11 (left down) and 12 (right down) March 2006. The red star corresponds to the Djougou (Benin) station. 
Table 2. Instantaneous (noon) regional mean $\left(9^{\circ}-17^{\circ} \mathrm{N}, 10^{\circ} \mathrm{W}-20^{\circ} \mathrm{E}\right)$ of TOA and surface (SRF) dust direct radiative forcing (in $\left.\mathrm{W} / \mathrm{m}^{2}\right)$ simulated in shortwave (SW) and longwave (LW) regions, associated with dust radiative efficiencies (in W/m²/DOD), (DOD: Dust Optical Depth).

\begin{tabular}{ccccccccc}
\hline TOA & SW & LW & SW & LW & SW & LW & SW & LW \\
Total & -0.9 & -2.5 & -7.3 & -2.9 & -25.0 & -0.6 & -14.1 & +1.6 \\
SRF & SW & LW & SW & LW & SW & LW & SW & LW \\
Total & -86.8 & -15.9 & -124.4 & -14.2 & -168.9 & -3.4 & -171.2 & +3.2 \\
& -102.7 & $(171.2)$ & -138.6 & $(167.0)$ & -172.3 & $(140.5)$ & -168.0 & $(148.7)$ \\
\hline & $\begin{array}{c}9 \text { March } \\
(D O D=0.60)\end{array}$ & $\begin{array}{c}10 \text { March } \\
(\mathrm{DOD}=0.83)\end{array}$ & $\begin{array}{c}111 \mathrm{March} \\
(\mathrm{DOD}=1.23)\end{array}$ & $\begin{array}{c}12 \mathrm{March} \\
(\mathrm{DOD}=1.13)\end{array}$ \\
\hline
\end{tabular}

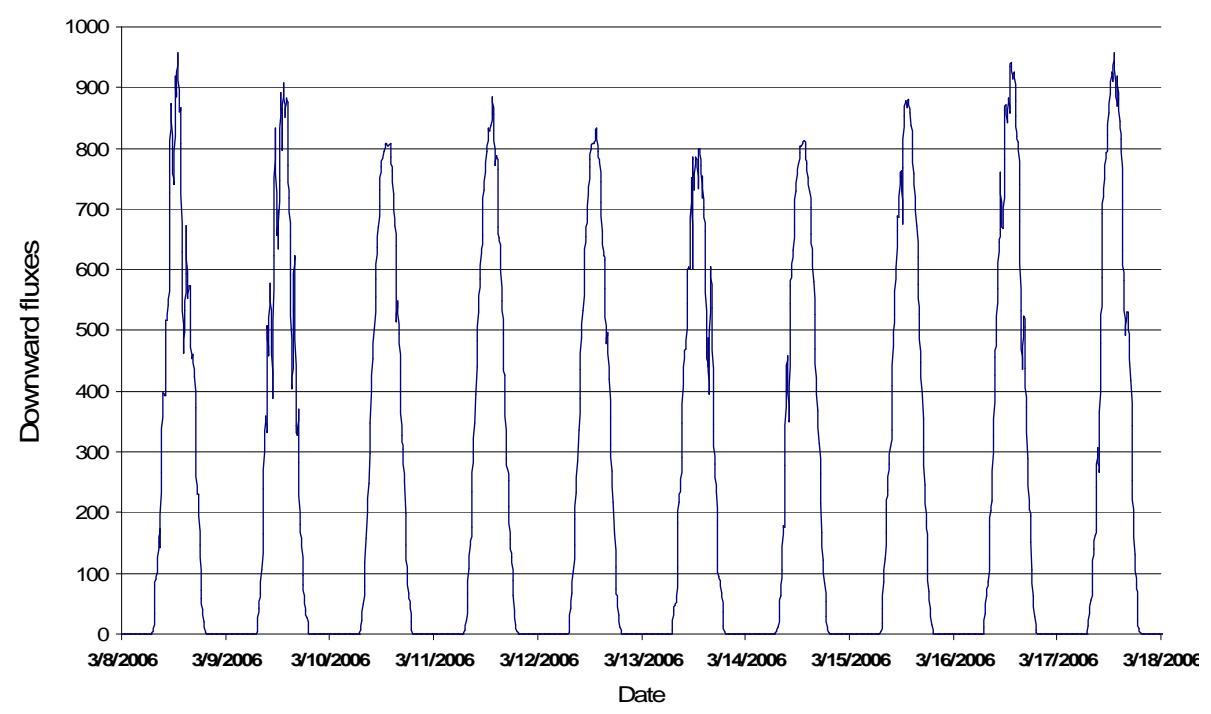

Fig. 5. Downward shortwave fluxes (in $\mathrm{W} / \mathrm{m}^{2}$ ) observed at Djougou from pyranometers (Kipp and Konen) measurements for the 8 to 18 March period.

As shown in the Fig. 4, SRF_SW (at noon) is almost everywhere negative with values comprised between $-200 \mathrm{~W} / \mathrm{m}^{2}$ and quite remarkable maxima of $-400 \mathrm{~W} / \mathrm{m}^{2}$. In addition to continental regions, significant effects are also observed over oceanic zones as Atlantic ocean $\left(\approx-200 /-300 \mathrm{~W} / \mathrm{m}^{2}\right)$ and Gulf of Guinea $\left(\approx-200 /-300 \mathrm{~W} / \mathrm{m}^{2}\right)$, especially for the 11 and 12 March, when dusts are advected southward of the domain. It should be outlined here that surface differences are "instantaneous" (not averaged for a day) and reported for a specific time (here at noon). Our results of simulations are shown to be quite consistent with downward solar fluxes as measured at Djougou (Fig. 5), showing a large decrease in solar downward fluxes (around $-150 \mathrm{~W} / \mathrm{m}^{2}$ ) during the dust outbreak (9-13 March).

Such a decrease has been also observed by Slingo et al. (2006) who reported that the dust storm dropped by around $250 \mathrm{~W} / \mathrm{m}^{2}$ the incoming solar fluxes at the surface at Niamey. Milton et al. (2008) modelled that dust particles considerably reduce net downward shortwave flux at the surface over a large part of West Africa with maximum of $200 \mathrm{~W} / \mathrm{m}^{2}$. In addition, in the framework of the AMMA program, Derimian et al. (2008) estimated the aerosol surface radiative forcing over M'Bour, Senegal. The estimations were based on the aerosol properties derived from AERONET retrievals and validated against broad-band radiation measurements conducted during AMMA campaign period at M'Bour observational site. The instantaneous surface radiative forcing obtained for $10 \mathrm{March}$ and for the midday time was of about $220 \mathrm{~W} / \mathrm{m}^{2}$, which is close to our simulation results. Direct comparisons (Fig. 6) between downward fluxes as simulated by MesoNH and observed from pyranometers at Djougou for the 10-12 March period, for pure clear-sky days (absence of clouds), show a relatively good agreement, even if a none negligible dispersion is also reported. Differences observed between simulated and measured solar downward fluxes are mainly due to the strong optical depth horizontal gradient together with the spatial resolution used in MesoNH $(12 \times 12 \mathrm{~km})$ 


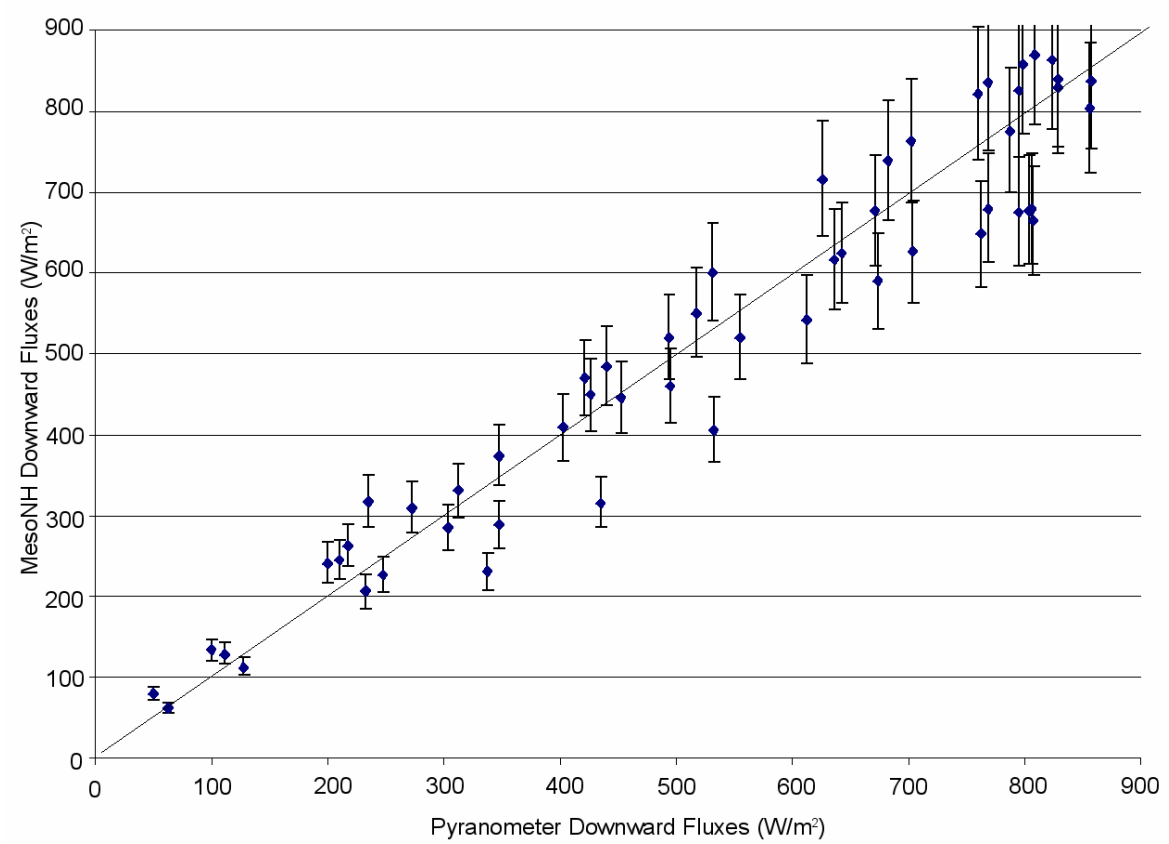

Fig. 6. Comparisons between downward shortwave fluxes simulated by MesoNH and measured at Djougou for the 10-12 period of March (pure clear-sky days). The solid line corresponds to 1:1 line.

Over West Africa, our results are found to be comparable with those $\left(-500<\right.$ SRF_SW $\left.<-200 \mathrm{~W} / \mathrm{m}^{2}\right)$ reported by Grini et al. (2006), who studied a dust outbreak occurring over Mauritania and Senegal by using the MesoNH model. Helmert et al. (2007) reported also values comprised between -200 and $-500 \mathrm{~W} / \mathrm{m}^{2}$ (simulated at noon) during a Saharan dust outbreak occurring in October 2001 by using the chemistry-transport model MUSCAT with a dust emission scheme.

Figure 4 displays some isolated positive values, with magnitudes comprised between +100 and $+200 \mathrm{~W} / \mathrm{m}^{2}$, over Ghana (9 March) and Southern Nigeria (above the Gulf of Guinea, for the 10 March), implying an increase of solar radiations reaching the surface when dust are included in simulations. As our calculations account for the atmospheric feedback, these changes are due to local modifications of cloud cover. On 10 March, a significant modification (not shown) in cloud cover appears between the control simulation (without dust radiative effect), where low clouds are developed over the Gulf of Guinea, and the second one (including dust effect), where clouds are dissipating. At this time, we do not know the processes responsible for modifying cloud cover over the region, and more detailed studies on this specific point has to be performed. As reported by Slingo et al. (2006), one process capable of modifying the clouds is the cold front that accompanied the dust outbreak.

Averaged at the regional scale $\left(9-17^{\circ} \mathrm{N} / 10^{\circ} \mathrm{W}-20^{\circ} \mathrm{E}\right)$, our simulations indicate instantaneous (at noon) SRF_SW (obtained for the 9, 10,11 and 12 March, see Table 2) comprised between -86.8 and $-171.2 \mathrm{~W} / \mathrm{m}^{2}$ (for dust AOD ranging from 0.60 and 1.23). These results clearly underline that dust aerosols produce a strong reduction of the incoming shortwave surface flux over a large part of the Western African region.

\subsubsection{Infrared spectral range}

We present here the dust surface forcing occurring now in the infrared spectral range (SRF_LW). The convention used is strictly similar to the one (relation 2) used for solar wavelengths. Before presenting our results, we remind here that MesoNH simulations could underestimate the surface longwave effect by up to 15\% (Dufresne et al., 2002), due to the fact that the scattering of longwave radiation is neglected.

In regional average, SRF_LW simulated for the 9, 10, 11 and 12 March (at noon) indicate values comprised between -16.0 and $+3.2 \mathrm{~W} / \mathrm{m}^{2}$ (mean of $-7.6 \mathrm{~W} / \mathrm{m}^{2}$, Table 2). It should be noted that values reported in Table 2 are regionally averaged. At local scale, dust particles can clearly increase LW radiations at the surface by $\sim 20-30 \mathrm{~W} / \mathrm{m}^{-2}$, with maxima reaching up to $100 \mathrm{~W} / \mathrm{m}^{-2}$ (not shown), what is consistent with the values reported by Bharmal et al. (2009). At Niamey, Slingo et al. (2006) reported that the downward thermal emission from the atmosphere display a significant peak on 7 March during the same dust outbreak.

By using transfer radiative models, Liao and Seinfeld (1998) reported diurnal longwave surface forcing comprised between +0.9 and $+1.4 \mathrm{~W} / \mathrm{m}^{2}$, depending of the dust 

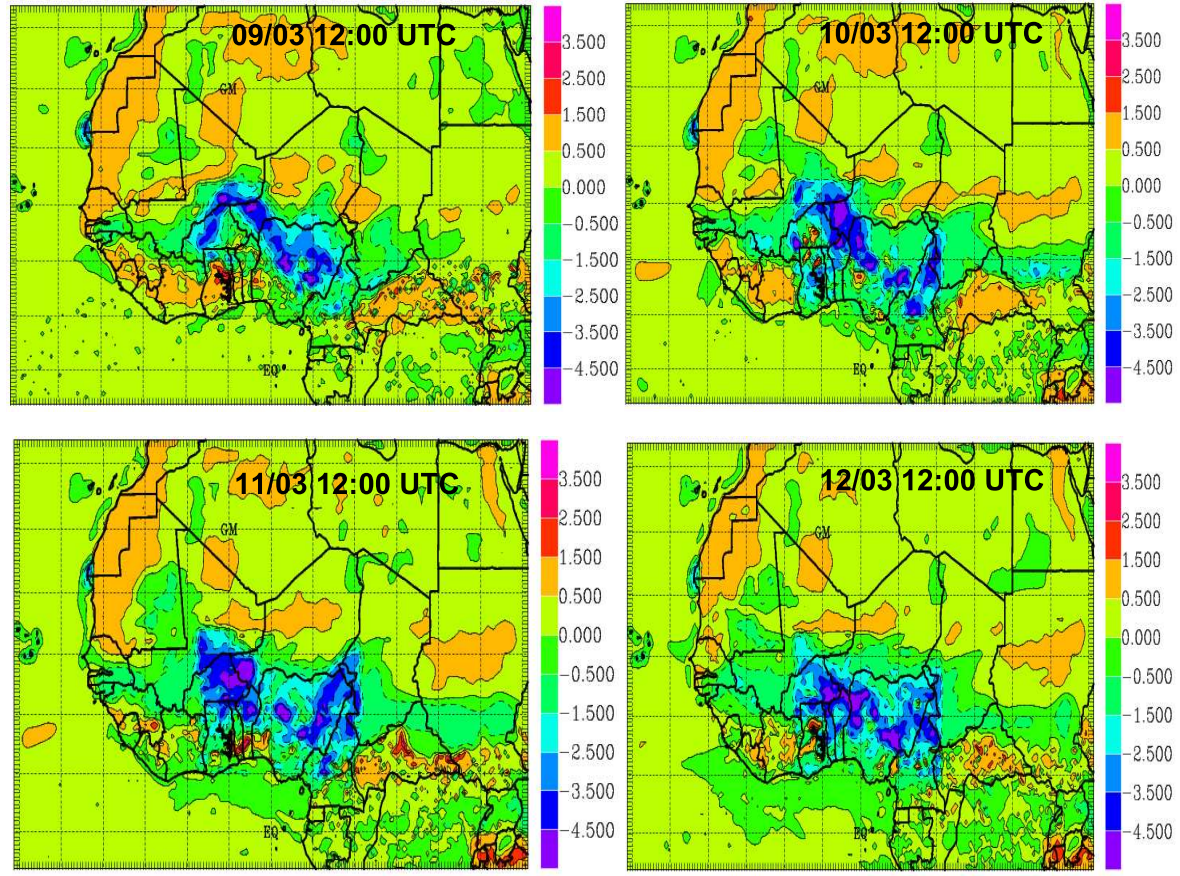

Fig. 7. Instantaneous change (at noon) in surface temperature simulated by MesoNH for the 9 (left up), 10 (right up), 11 (left down) and 12 (right down) March 2006.

layer altitude. Dufresne et al. (2002) indicate also positive surface forcings comprised between +21 and $+29 \mathrm{~W} / \mathrm{m}^{2}$, for six different atmospheric profiles. Finally, three dimensional modelling have been performed by Yoshioka et al. (2007), who reported a mean annual value of $+14 \mathrm{~W} / \mathrm{m}^{2}$ over the North Africa region, by using the CCSM3 model.

Before presenting the effect of mineral dust on the top of atmosphere (part 5.3) outgoing radiations, we discuss here the impact of the net (shortwave plus longwave) surface dimming on surface temperature and surface energy budget, by using sensible heat fluxes measurements.

\subsection{Effect of dust surface dimming on the surface temperature and sensible heat fluxes}

Changes in air surface temperatures due to dust surface dimming, $\Delta T$, has been calculated as the difference between the surface temperature simulated with and without dust. Results obtained for the 9, 10, 11 and 12 March (at 12:00 UTC) are reported in the Fig. 7, indicating a significant decrease in the air surface temperature when dusts are included in simulations. Comparisons between the geographical patterns of the air surface temperature change and dust AOD distribution (Fig. 1) clearly show that the strongest decrease are related to highest dust AOD. As observed in the Fig. 7, the change in air surface temperature can be locally significant, as over Northern Benin (with a mean change of $-2.8^{\circ} \mathrm{C}$, for the 9 to
12 March period) or over Western Nigeria (mean of $-3.7^{\circ} \mathrm{C}$, for the 9 to 12 March period). At Niamey, Slingo et al. (2006) reported a drop in the daytime maximum temperature of about $10^{\circ} \mathrm{C}$ few days after the passage of the dust outbreak. At Djougou, we have observed a decrease of the air surface temperature up to $2^{\circ} \mathrm{C}$ (at noon), associated with an increase of the temperature during night time (up to $2^{\circ} \mathrm{C}$ at 04:00 a.m.) due to the longwave trapping by dust and re-emission. In our simulations, dust aerosol induces a surface temperature decrease of about $0.68^{\circ} \mathrm{C}$ (at noon) averaged over a $9^{\circ}-17^{\circ} \mathrm{N}$, $10^{\circ} \mathrm{W}-20^{\circ} \mathrm{E}$ region, for 9-12 March period. However and as mentioned by Slingo et al. (2006), it should be noted that the net (shortwave+longwave) radiative heating of the atmosphere increases for all days (Table 2). Despite this increased radiative heating, the lower troposphere cools during the dust event at Djougou, which illustrates the associated contribution of a relatively cool air flowing in from the desert. This cooling could have a significant impact on the lower troposphere dynamics. This particular point will be discussed in the last part of this study (4.4).

As mentioned in the introduction, one of the interests here concerns the effect of the dust surface dimming on surface energy budget. For that purpose, we have used MesoNH simulations together with experimental observations of sensible heat fluxes $(H)$ performed at Djougou. This approach is quite important because of the surface balance between radiation, evaporation (latent heat flux from the surface to the 

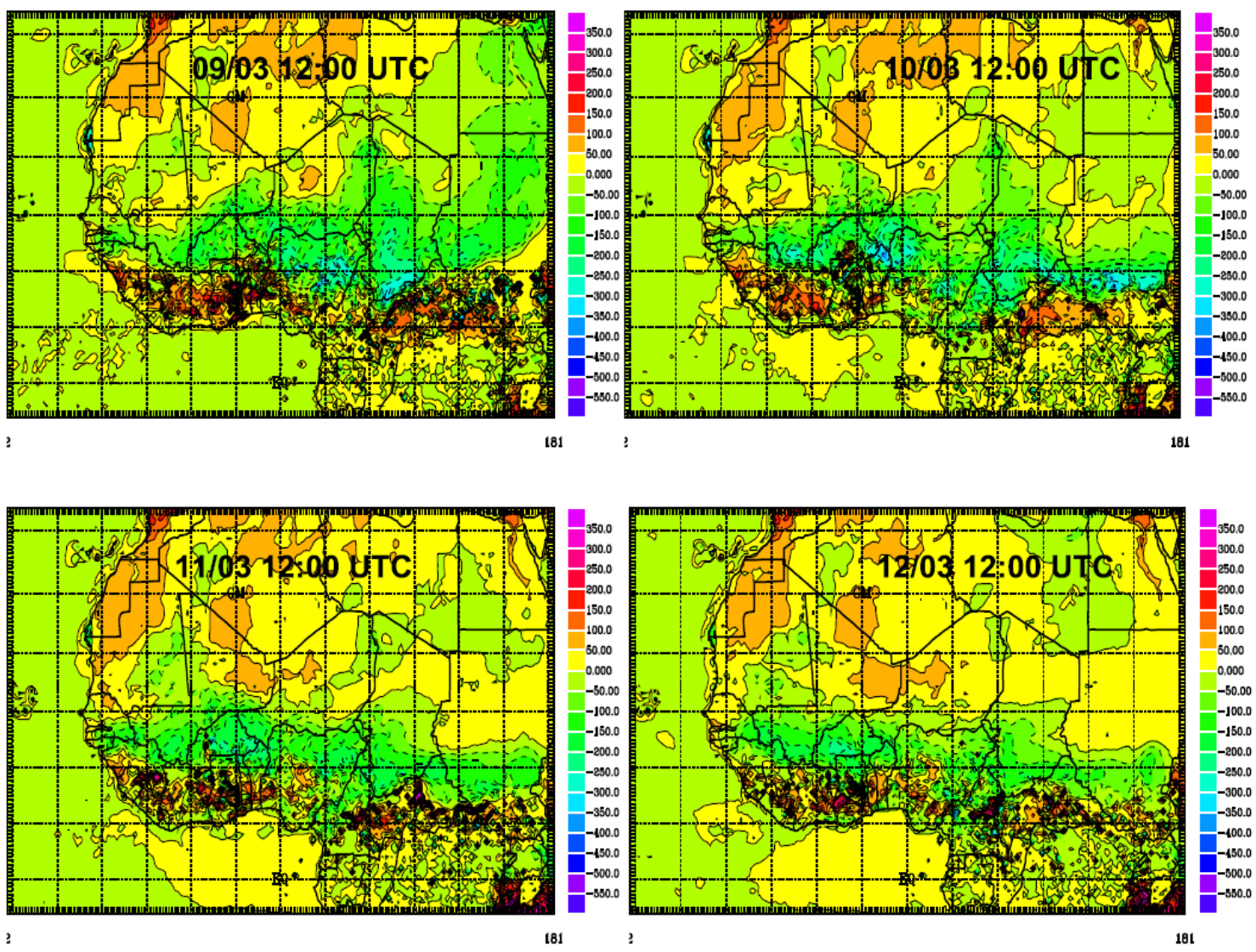

Fig. 8. Instantaneous change in surface sensible fluxes (at noon) between "dust" and "no-dust" MesoNH simulations for the 9 (left up), 10 (right up), 11 (left down) and 12 (right down) March 2006.

atmosphere) and sensible heat flux. One or all of these components will decrease to compensate for the reduction of total (except in certain cases in the longwave region; Slingo et al., 2006; Miller et al., 2009) surface solar radiation. At this time and except the work of Grini et al. (2006) and Miller et al. (2009), few works have documented the possible effect of dust particles on the surface energy budget over the Western Africa region. Most of all, no studies have coupled modelling exercises with observational dataset over the region.

As for the surface temperature, the impact of dust on sensible heat fluxes has been determined by the difference between simulated HDUST and HNONE, which are the surface sensible heat fluxes in interactive dust simulations and in the control run, respectively. Our results are reported in the Fig. 8, showing $\Delta H$ for the 9,10,11 and 12 March (at noon), underlying intense decreases, with maxima of $200 \mathrm{~W} / \mathrm{m}^{2}$ corresponding to higher dust AOD. Over Benin, simulations indicate a decrease of about $\sim 100-150 \mathrm{~W} / \mathrm{m}^{2}$, what is conjointly observed from experimental measurements at Djougou (Fig. 9), showing that the dust storm dropped by around $100-150 \mathrm{~W} / \mathrm{m}^{2}$ the surface sensible fluxes. As an example of results, $H$ is changing from 270 to $150 \mathrm{~W} / \mathrm{m}^{2}$, for the 11 and 13 March, respectively (at noon). Although the model well captures the decrease of sensible heat fluxes at the surface, direct comparisons (not shown) are not conclusive due to the difference observed between simulated and measured dust optical depth at Djougou (Tulet et al., 2008). A second explanation could come from the resolution used $(12 \times 12 \mathrm{~km})$ in our simulations, which is maybe not adapted to conduct direct comparisons.

For comparisons, Fan et al. (2008) reported a decrease of about $20-30 \mathrm{~W} / \mathrm{m}^{-2}$ in sensible heat fluxes in case of considerably lower AOD $(0.27$ at $550 \mathrm{~nm})$. Jiang and Feingold (2006) indicated larger effects on surface heat fluxes (sum of sensible and latent heat fluxes), with a decrease of about $100 \mathrm{~W} / \mathrm{m}^{2}$ (at noon) for AOD around 1. For biomass burning aerosols, Feingold et al. (2005) showed a reduction of $60 \mathrm{~W} / \mathrm{m}^{2}$ in the sensible heat fluxes (AOD of 0.6). It should be noted that these results were obtained from modelling exercises and not reinforced by experimental observations, as proposed in this work. 


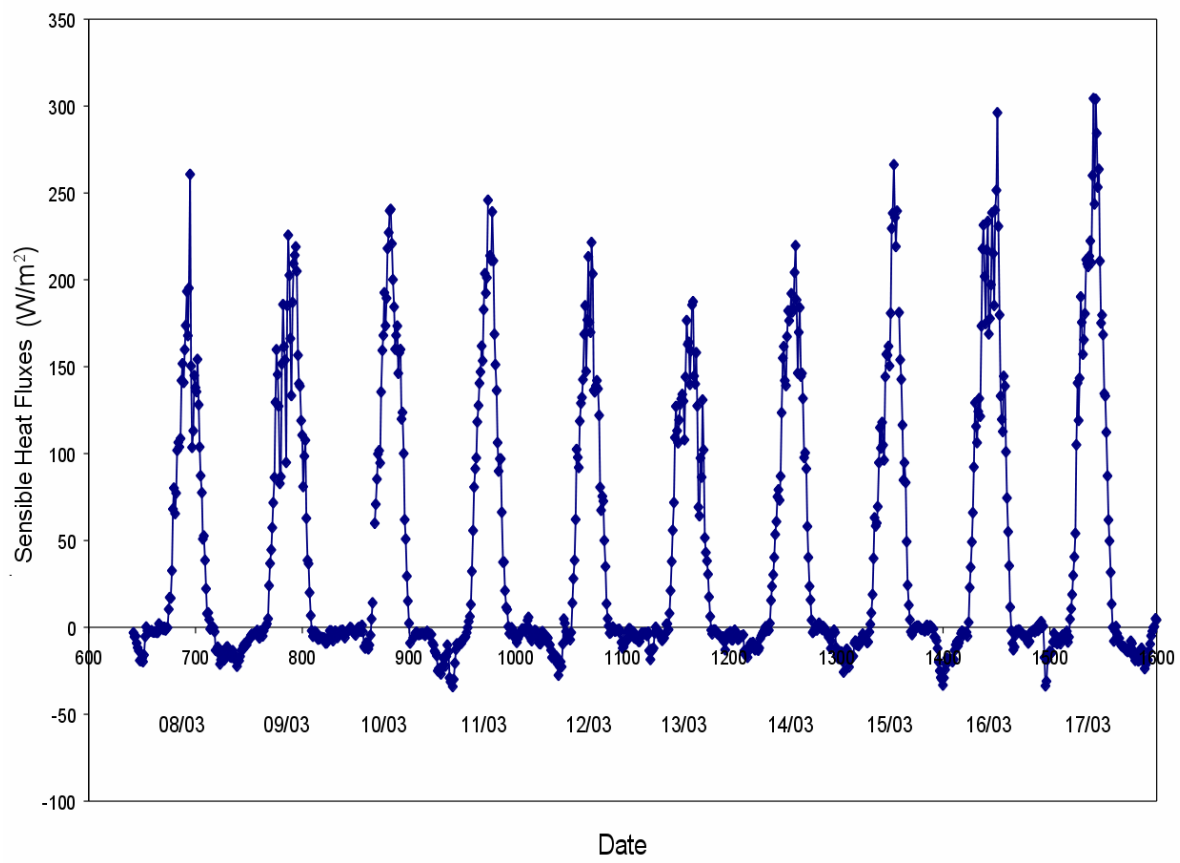

Fig. 9. Sensible heat fluxes (in W/m $\mathrm{m}^{2}$ ) estimated at Djougou (Northern Benin) during the 8 to 17 March period by using the eddy covariance method (see Sect. 2).

\subsection{Dust effect on the top of atmosphere outgoing radiation}

As mentioned in the Sect. 5.1, we discuss here about the effect of dust on Top Of Atmosphere (TOA) outgoing radiation, both in shortwave and longwave spectral ranges. We characterise this effect by calculating the flux difference: TOA_SW=(SW_UP)NONE-(SW_UP)DUST, where SW_UP is the upward shortwave radiative fluxes (in $\mathrm{W} / \mathrm{m}^{2}$ ). Once again, with this relation, a negative sign of TOA_SW (or TOA_LW) implies an overall cooling effect at TOA and a positive one a heating effect. Sensitivity tests reported in the Table 1 display significant uncertainties in the TOA dust forcing, mainly due to errors in the surface albedo. Our calculations indicate that uncertainties can vary between $-40 \%$ and $+15 \%$, depending on the parameters tested.

\subsubsection{Solar spectral range}

Figure 10 displays the difference in upward shortwave fluxes, with and without aerosols, for the 9, 10, 11 and 12 March (at noon). Our simulations reveal a significant North-South gradient over West Africa. Two different zones appear, with a first one $\left(16^{\circ}-21^{\circ} \mathrm{N} / 10^{\circ} \mathrm{E}-20^{\circ} \mathrm{W}\right)$ characterized by simulated positive values, with a regional mean of $+5.3 \mathrm{~W} / \mathrm{m}^{2}$ and local maximums reaching up to $+100 \mathrm{~W} / \mathrm{m}^{2}$. The second one $\left(7^{\circ}-14^{\circ} \mathrm{N} / 1^{\circ} \mathrm{E}-15^{\circ} \mathrm{W}\right)$ is characterized by a mean regional of $-6.6 \mathrm{~W} / \mathrm{m}^{2}$, with maximums reaching up to $-100 \mathrm{~W} / \mathrm{m}^{2}$, what is consistent with values reported by Slingo et al. (2006) who indicated that reflected fluxes at the TOA rose by $100 \mathrm{~W} / \mathrm{m}^{2}$ at Niamey. Our simulation for 10 March over Senegal is also in agreement with the instantaneous TOA forcing calculated by Derimian et al. (2008) in M'Bour, which range from about -70 to $-90 \mathrm{~W} / \mathrm{m}^{2}$ (at noon). In addition, Milton et al. (2008) reported values comprised between -10 and $-80 \mathrm{~W} / \mathrm{m}^{2}$ over the Sahel region.

This result implies two opposite effects with a heating and cooling of the "Earth-Atmosphere" system over different zones. Such opposite effect is mainly due to decreasing North-South surface albedo gradient. Concerning the second one $\left(7^{\circ}-14^{\circ} \mathrm{N} / 1^{\circ} \mathrm{E}-15^{\circ} \mathrm{W}\right)$, the combined aerosolsurface system reflects more solar radiations back to space than the surface associated with a clean atmosphere. Similar results are obviously obtained over oceanic regions, expected over the Gulf of Guinea. Over the first zone (14 ${ }^{\circ}$ $\left.21^{\circ} \mathrm{N} / 1^{\circ} \mathrm{E}-15^{\circ} \mathrm{W}\right)$, the presence of dust above high reflectivity areas reduces upward fluxes compared to a surface of a specific albedo alone. Over such regions, mineral aerosols warm the "Earth-Atmosphere" system.

Over the Gulf of Guinea in Nigeria, a large positive TOA effect is obtained for the 10 and 12 March, with values ranging from +100 to $200 \mathrm{~W} / \mathrm{m}^{2}$. As reported in the part 5.1.1, this effect is due to changes in the cloud cover. In case of simulations including dust aerosols, low clouds cover is decreasing over the gulf of Guinea, leading to lesser solar fluxes reflected back to space.

In term of regional average (Table 2), the shortwave TOA direct radiative effect is negative with minimum values (at 

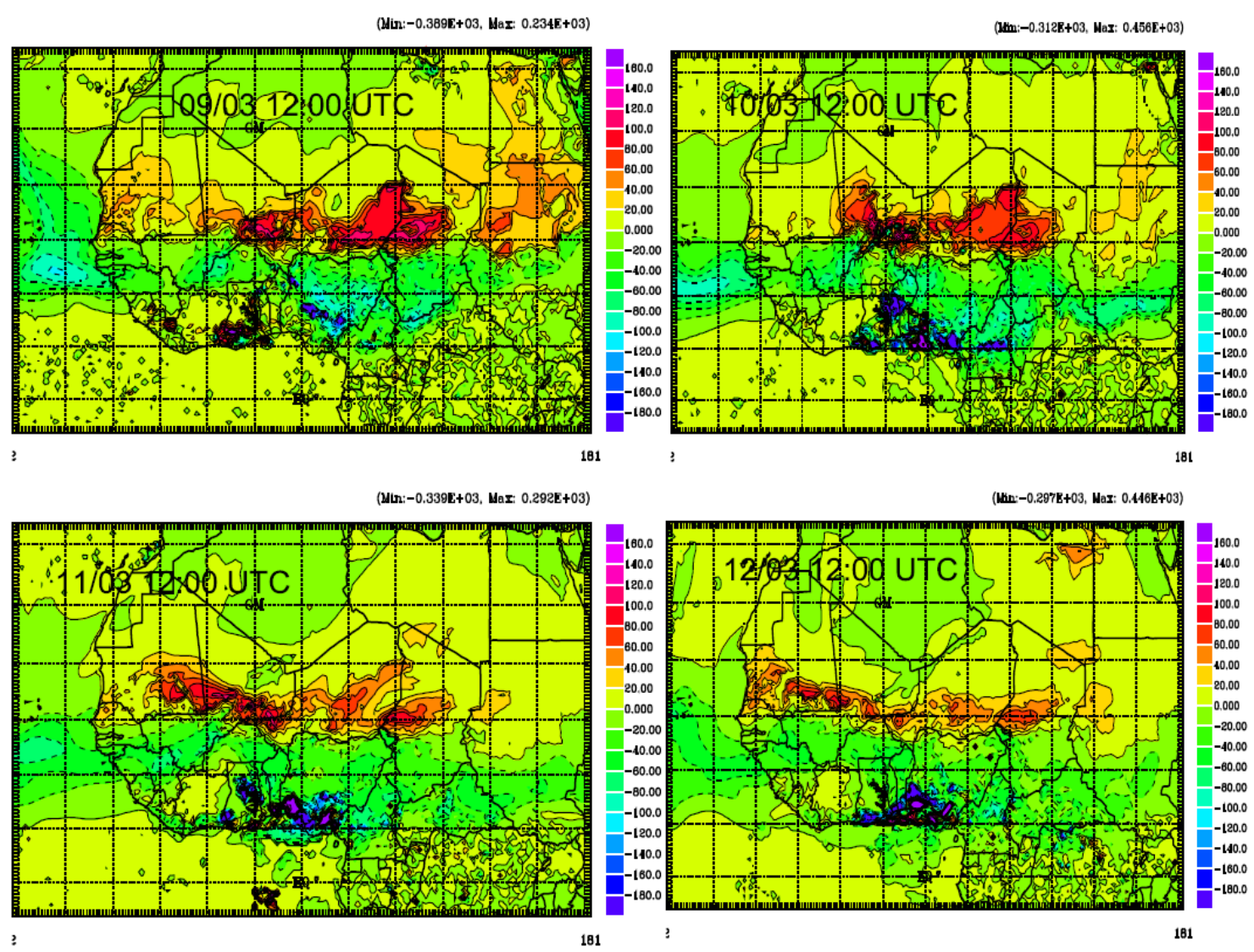

Fig. 10. Instantaneous (noon) dust TOA shortwave direct effect (in $\mathrm{W} / \mathrm{m}^{2}$ ) simulated by MesoNH for the 9 (left up), 10 (right up), 11 (left down) and 12 (right down) March 2006.

noon) of $-0.9 \mathrm{~W} / \mathrm{m}^{2}$ for the 9 March, when most of the mineral dust is located in majority north of the domain (i.e. above high surface albedo). The maximum regional mean $\left(-25.0 \mathrm{~W} / \mathrm{m}^{2}\right)$ is simulated for the 11 March, when dust aerosols are advected South of the domain above low surface albedos, associated with largest mean dust AOD (1.23). To summarize, dust particles are shown to heat and/or cool the "Earth-Atmosphere" system in the solar range, depending on the surface albedo. Results of simulations reported in the Table 2 indicate that dust aerosols always cool the "Earth-Atmosphere" system (in the solar range) at the regional scale.

\subsubsection{Infrared spectral range}

Dust effect on TOA longwave radiations (TOA_LW) are reported in the Fig. 11, for 9, 10, 11 and 12 March (at noon). At the regional scale, our results indicate that dust aerosols generally produce a negative effect over the entire West Africa region $\left(9^{\circ}-17^{\circ} \mathrm{N}, 10^{\circ} \mathrm{W}-20^{\circ} \mathrm{E}\right)$, with instantaneous (12:00 UTC) values comprised between -2.9 and $+1.6 \mathrm{~W} / \mathrm{m}^{2}$ (mean of $-1.1 \mathrm{~W} / \mathrm{m}^{2}$ ). However and as shown in the Fig. 11, TOA_LW can locally be positive at local scale and reach up to $+30-40 \mathrm{~W} / \mathrm{m}^{2}$, what is consistent with Slingo et al. (2006), who derived the Outgoing Longwave Radiation (ORL) from the GERB broadband radiometer and show large signals during this dust outbreak, with a significant decrease by about $30 \mathrm{~W} / \mathrm{m}^{2}$ at midday. This result is found to be consistent with the analysis of previous dust storms by Haywood et al. (2005).

\subsection{Effect of the dust on heating rate profiles and convective activity}

\subsubsection{Solar and infrared heating rates}

Figure 12 reported the difference between HR_SW simulated by using two parallel simulations for the $9,10,11$ and 12 March (at noon). First, it is seen that dust HR_SW are linked with the vertical structure of the dust plumes. Dust aerosols induce a significant perturbation in solar heating rates ranging from +4.0 to $+7.0 \mathrm{~K}$ by day (at midday) and occurring in majority within the $2-4 \mathrm{~km}$ dusty layer. The absorption within the dusty layer, together with the scattering, cuts down the incoming solar flux thus decreasing the heating rates of the air below the dust layer (Fig. 12). 

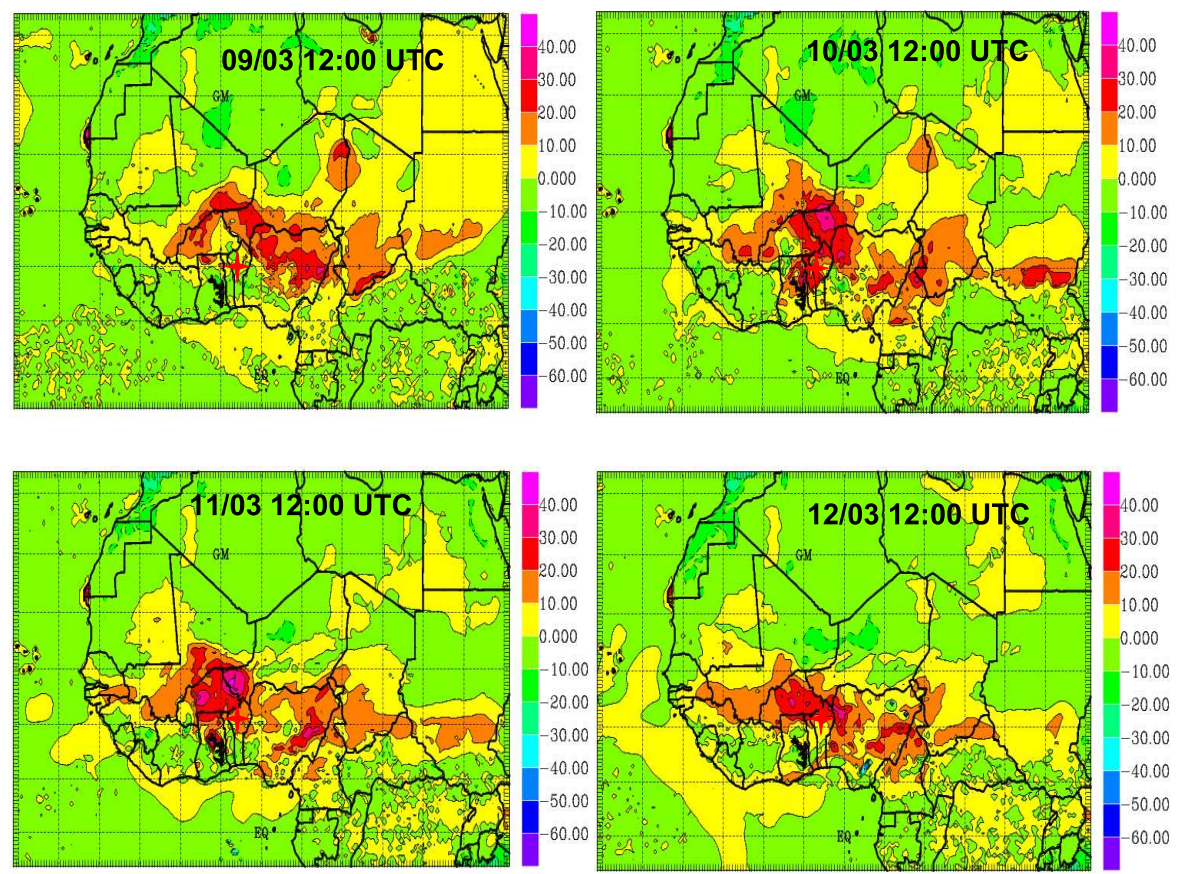

Fig. 11. Instantaneous (noon) dust TOA longwave direct effect (in W/m ${ }^{2}$ ) simulated by MesoNH for the 9 (left up), 10 (right up), 11 (left down) and 12 (right down) March 2006.
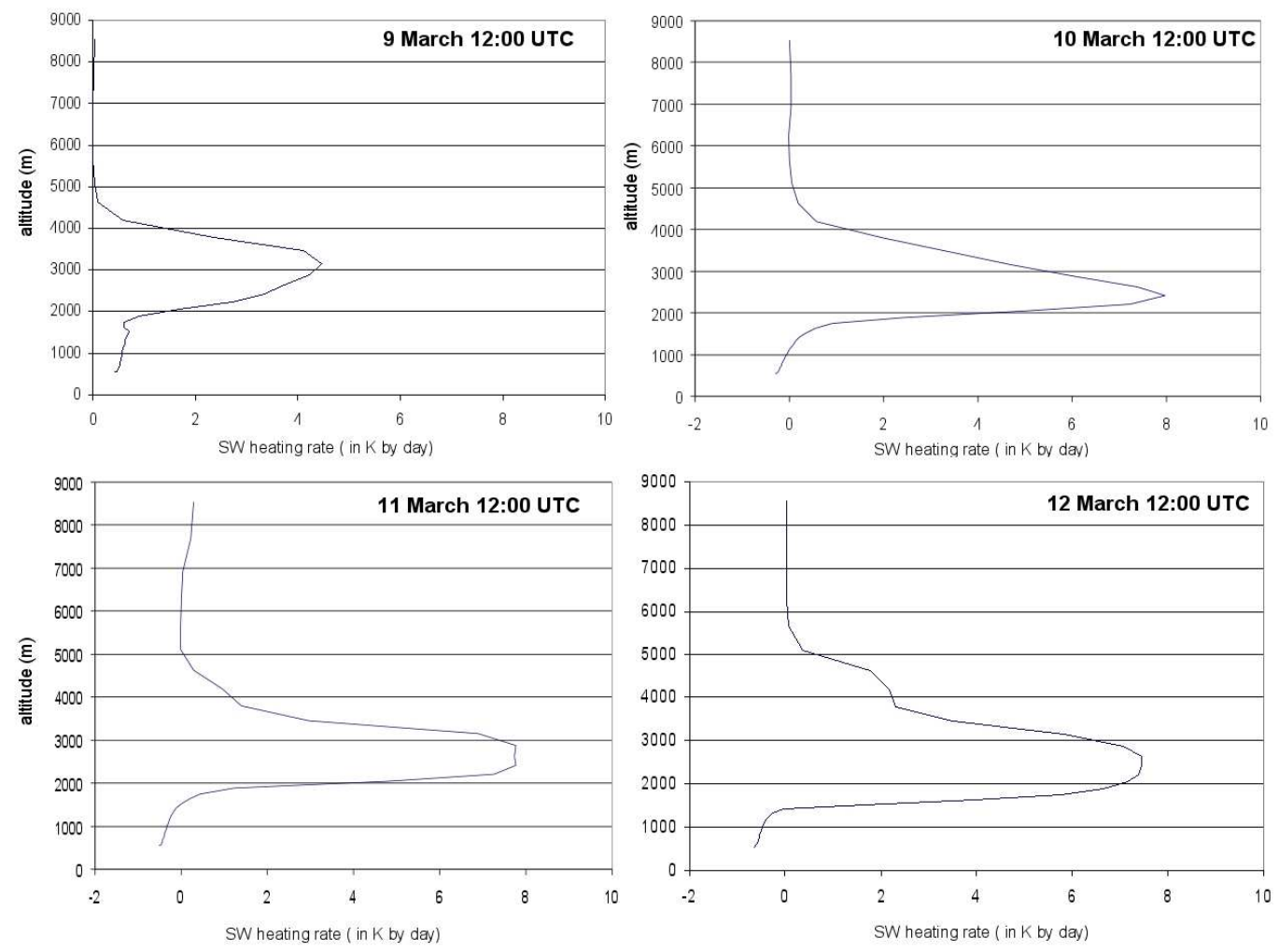

Fig. 12. Regional averaged $\left(9^{\circ}-17^{\circ} \mathrm{N}, 10^{\circ} \mathrm{W}-20^{\circ} \mathrm{E}\right)$ of dust aerosol-induced perturbations in the solar heating rates (in $\mathrm{K}$ by day) at 12:00 UTC, for the 9 (left up), 10 (right up), 11 (left down) and 12 (right down) March 2006. 

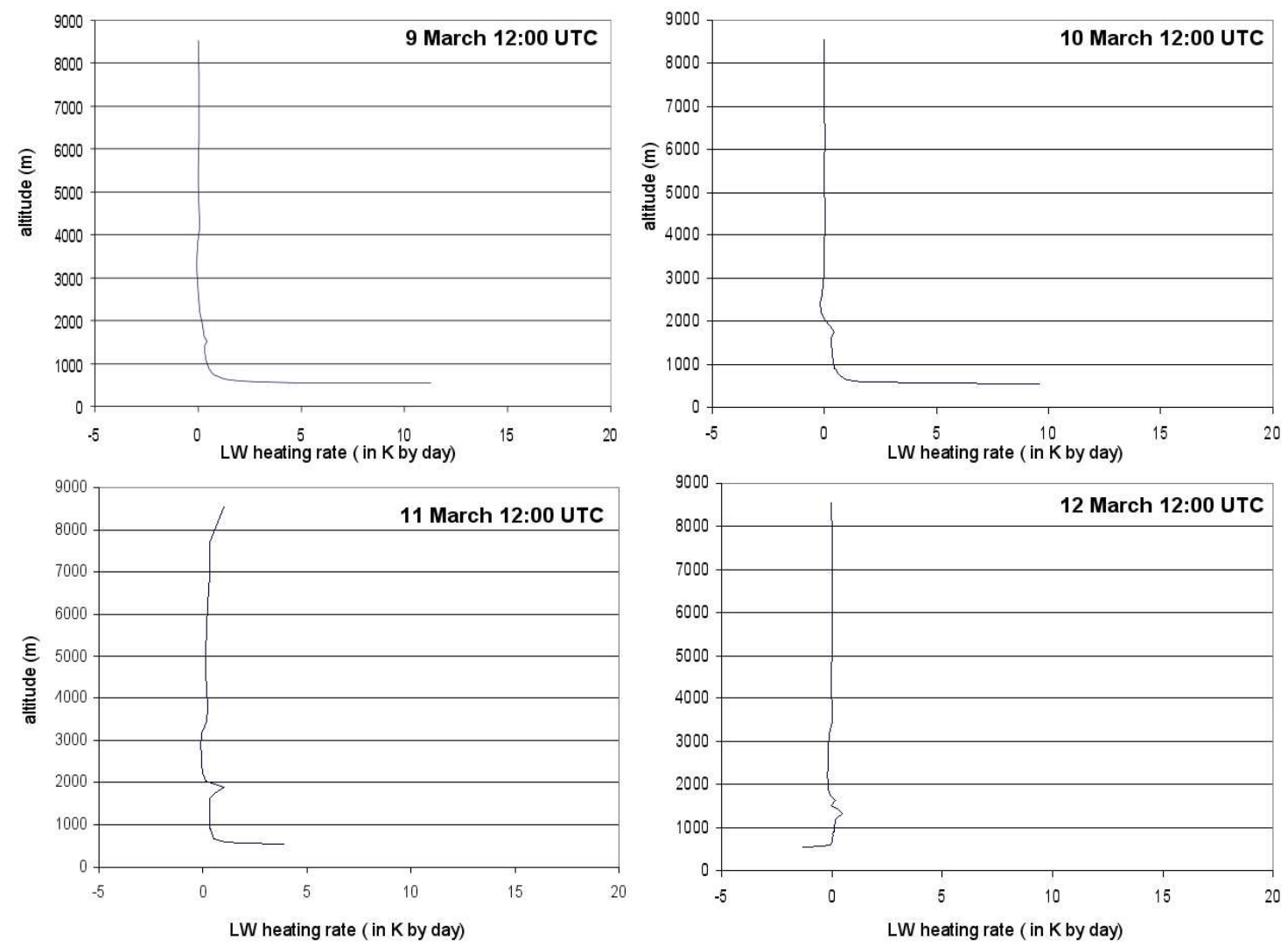

Fig. 13. Regional averaged $\left(9-17^{\circ} \mathrm{N}, 10^{\circ} \mathrm{W}-20^{\circ} \mathrm{E}\right)$ of dust aerosol-induced perturbations in the infrared heating rates (in $\mathrm{K}$ by day) at 12:00 UTC, for the 9 (left up), 10 (right up), 11 (left down) and 12 (right down) March 2006.

For comparisons, at Niamey, McFarlane et al. (2009) reported SW heating rate on 21 January 2006 of about 3.0$4.0 \mathrm{~K}$ by day (at midday) in the $0-1 \mathrm{~km}$ layer, largely due to mineral dust aerosols. Higher values $(\sim 5 \mathrm{~K}$ by day at midday) are obtained in the $3-4 \mathrm{~km}$ layer, due to the presence of highly absorbing biomass burning particles. Mohalfi et al. (1998) reported vertical distributions of shortwave heating rates (at noon) due to dust aerosols only over the Saudi desert as function of AOD. Results indicated maximum heating of 3.0, 4.5 and $6.5 \mathrm{~K}$ by day, corresponding to AOD of $0.5,1.5$ and 3, respectively. Kim et al. (2004) reported instantaneous vertical profiles of shortwave heating rates obtained onboard the C-130 research flight during Asian dust events, showing values comprised between 2 and $5 \mathrm{~K}$ by day in the dusty layer. Although obtained for a different site, these estimations are found to be coherent with HR_SW as simulated by MesoNH.

Figure 13 shows estimations of HR_LW due to dust particles, for the 9,10,11 and 12 March (at noon). Results show LW cooling within the dusty layer for each day, with values ranging from -0.10 to $-0.20 \mathrm{~K}$ by day. This effect is quite consistent to those found in the literature. As an example, Mohalfi et al. (1998) reported $-1 \mathrm{~K}$ by day over Saudi
Arabia and Kim et al. (2004) reported HR_LW values ranging from -2 to $-4 \mathrm{~K}$ by day in the dusty layer over Asian region. At the surface, dust aerosols lead to positive HR_LW, with values comprised between +4 and $+9 \mathrm{~K}$ by day.

\subsubsection{Impact of dust radiative effect on the convective activity}

In order to investigate the possible effect of dust on the convective activity, we have used the mean regional convective available potential energy (CAPE) as simulated by MesoNH for 9, 10, 11 and 12 March (at noon). Our results are reported in the Fig. 14. It should be recalled that in a case of convectively unstable atmosphere, CAPE is greater than zero and increases when the temperature or moisture in the boundary layer increases (or the upper layer temperature decreases). In a stable atmosphere, CAPE is zero and changes of temperature or moisture do not affect CAPE unless the changes are large enough to make the atmosphere unstable.

In Fig. 14, we have reported CAPE vertical profiles of the difference between MesoNH simulations including or not dust aerosols. Results of simulations show a remarkable decrease between the surface and $2 \mathrm{~km}$ height with a value 


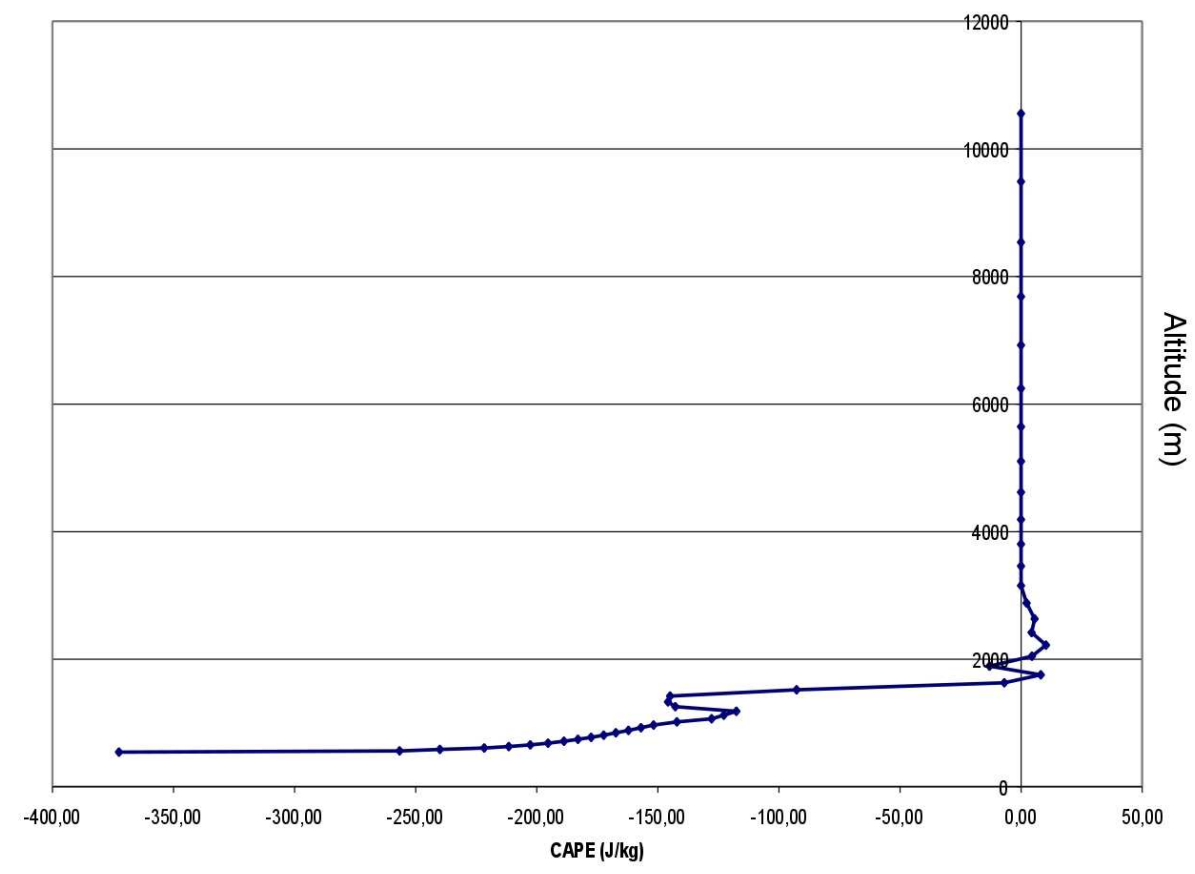

Fig. 14. Regional averaged $\left(9-17^{\circ} \mathrm{N}, 10^{\circ} \mathrm{W}-20^{\circ} \mathrm{E}\right.$ ) of dust aerosol-induced perturbations in CAPE (in $\mathrm{J}$ by $\mathrm{kg}$ ) at 12:00 UTC, averaged of the 9,10,11 and 12 March (at noon).

reaching up to $-350 \mathrm{~J}$ by $\mathrm{kg}$ at the surface. Although only obtained through modelling exercises and not validated by in-situ observations at this time, this indicates the potential decrease of the convection processes due to dust radiative effects over the West African region.

This work seems to confirm results previously obtained by Grini et al. (2006) over the Sahel region by using MesoNH and simulations conducted by Jiang and Feingold (2006), Fan et al. (2008) or Wendisch et al. (2008), who show that the reduction of surface incoming radiation due to aerosols produce a weaker convective atmosphere.

\section{Conclusions}

A study of the dust aerosol impacts on the radiative effect, surface energy budget (surface temperature and sensible heat fluxes), heating rate profiles and convective activity over West Africa is presented. The study is based on numerical MesoNH simulations coupled with experimental AMMA observations obtained at Djougou (Benin) during an intense dust event (7-14 March). Two numerical simulations have been conducted: one including the radiative effects of dust aerosols and another without. The major results are the following:

- The presence of dust particles induces a large instantaneous (at noon) reduction of surface incoming shortwave radiation (with a regional mean of $-137 \mathrm{~W} / \mathrm{m}^{2}$ ) over a large part of West Africa $\left(9^{\circ}-17^{\circ} \mathrm{N}, 10^{\circ} \mathrm{W}-\right.$ $20^{\circ} \mathrm{E}$ ) during the 9 to 12 March period.

- The surface dimming resulting from the presence of dust is shown to cause important reductions in both the surface temperature (up to $4^{\circ} \mathrm{C}$ at midday over regions where high AOD occur) and in sensible heat fluxes (up to $100 \mathrm{~W} / \mathrm{m}^{2}$ ).

- The net effect (shortwave+longwave) at TOA is shown to be dominated by the SW direct forcing with a regional mean of $-12.0 \mathrm{~W} / \mathrm{m}^{2}$. As a result, the presence of dust plumes cools the Earth-Atmosphere system.

- The atmospheric heating rate changes induced by dust show large SW heating (at noon) within the dusty layer $(2-4 \mathrm{~km})$ due to strong absorption of the incoming solar radiation, with the maximum heating comprised between +4.0 and $+7.0 \mathrm{~K}$ by day. In the LW, a cooling effect is obtained within the dust layer, with values comprised between -0.10 and $-0.20 \mathrm{~K}$ by day.

- The surface cooling and reduction of energy fluxes associated with aerosol heating in the dust layer results, in our a case, in a reduction of convective activity, with a mean regional decrease of CAPE reaching about $200 \mathrm{~J} \mathrm{~kg}^{-1}$ between the surface and $2 \mathrm{~km}$ height.

- Further studies should be conducted for investigating the impact of mineral dust on the stratocumulus clouds cover over the Gulf of Guinea. 
Acknowledgements. Based on a French initiative, AMMA was built by an international scientific group and is currently funded by a large number of agencies, especially from France, UK, US and Africa. It has been the beneficiary of a major financial contribution from the European Community's Sixth Framework Research Programme. Detailed information on scientific coordination and funding is available on the AMMA International website http://www.amma-international.org.

Edited by: P. Formenti

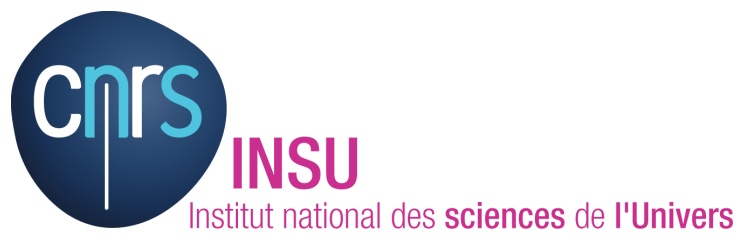

The publication of this article is financed by CNRS-INSU.

\section{References}

Abel, S. J., Highwood, E. J., Haywood, J. M., and Stringer, M. A.: The direct radiative effect of biomass burning aerosols over southern Africa, Atmos. Chem. Phys., 5, 1999-2018, 2005, http://www.atmos-chem-phys.net/5/1999/2005/.

Affre, C., Lopez, A., Carrara, A., Druilhet, A., and Fontan, J.: The analysis of energy and ozone flux data from the LANDES 94 experiment, Atmos. Environ. 2000, 34, 803-821, 2000.

Bellouin, N., Boucher, O., Vesperini, M., and Tanre, D.: Estimating the direct aerosol radiative perturbation: Impact of ocean surface representation and aerosol non-sphericity, Q. J. Roy. Meteorol. Soc., 130, 2217-2232, 2004.

Beverland, I. J., Moncrieff, J. B., Ónéill, C., Hargreaves, K. J., and Milne, R.: Measurement of methane and carbon dioxide fluxes from peatland ecosystems by the conditional-sampling technique, Q. J. Roy. Meteorol. Soc., 122, 819-838, 1996.

Bharmal, N. A., Slingo, A., Robinson, G. J., and Settle, J. J.: Simulation of surface and top of atmosphere thermal fluxes and radiances from the RADAGAST experiment, in press in JGR Atmosphere, 2009.

Bierwirth, E., Wendisch, M., Ehrlich, A., et al.: Spectral surface albedo over Morocco and its impact on radiative forcing of Saharan dust, Tellus, 61B, 252-269, doi:10.1111/j.16000889.2008.00395, 2009.

Derimian, Y., Léon, J.-F., Dubovik, O., et al.: Radiative properties of aerosol mixture observed during the dry season 2006 over M'Bour, Senegal (African Monsoon Multidisciplinary Analysis campaign), J. Geophys. Res., 113, D00C09, doi:10.1029/2008JD009904, 2008.

Dubovik, O. and King, M. D.: A flexible inversion algorithm for retrieval of aerosol optical properties from Sun and sky radiance measurements, J. Geophys. Res., 105, 20673-20696, 2000.

Dubovik, O., Holben, B. N., Eck, T. F., Smirnov, A., Kaufman, Y. J., King, M. D., Tanré, D., and Slutsker, I.: Variability of absorption and optical properties of key aerosol types observed in worldwide locations, J. Atmos. Sci., 59, 590-608, 2002.
Dubovik, O., Sinyuk, A., Lapyonok, T., et al.: Application of light scattering by spheroids for accounting for particle non-sphericity in remote sensing of desert dust, J. Geophys. Res., 111, D11208, doi:10.1029/2005JD006619d, 2006.

Dufresne, J. L., Gautier, C., Ricchiazzi, P., and Fouquart, Y.: Longwave Scattering Effects of Mineral Aerosols, J. Atmos. Sci., 59, 1959-1966, 2002.

Eck, T. F., Holben, B. N., Reid, J. S., et al.: Spatial and temporal variability of column-integrated aerosol optical properties in the southern Arabian Gulf and United Arab Emirates in summer, J. Geophys. Res., 113, D01204, doi:10.1029/2007JD008944, 2008.

Fan, J., Zhang, R., Tao, W.-K., and Mohr, K. I.: Effects of aerosol optical properties on deep convective clouds and radiative forcing, J. Geophys. Res., 113, D08209, doi:10.1029/2007JD009257, 2008.

Feingold, G., Jiang, H., and Harrington, Y.: On smoke suppression of clouds in Amazonia, Geophys. Res. Lett., 32, L02804, doi:10.1029/2004GL021369, 2005.

Foken, T. and Wichura, B.: Tools for quality assessment of surfacebased flux measurements, Agr. Forest Meteorol., 78, 83-105, 1996.

Fouquart, Y. and Bonnel, B.: Computation of solar heating of the Earth's atmosphere: A new parametrization, Cont. Atmos. Phys., 53(1), 35-62, 1980.

Fraser, R. S. and Kaufman, Y.: The relative importance of scattering and absorption in remote Sensing, IEEE T. Geosci. Remote, 23, 625-633, 1985.

Grini, A., Tulet, P., and Gomes, L.: Dusty weather forecasts using the MesoNH mesoscale atmospheric model, J. Geophys. Res., 111, D19205, doi:10.1029/2005JD007007, 2006.

Haywood, J. M. and Shine, K. P.: The effect of anthropogenic sulphate and soot on the clear-sky planetary radiation budget, Geophys. Res. Lett., 22, 603-606, 1995.

Haywood, J. M., Francis, P., Osborne, S., et al.: Radiative properties and direct radiative effect of Saharan dust measured by the C-130 aircraft during SHADE : 1, Solar spectrum, J. Geophys. Res., 108(D18), 8577, doi:10.1029/2002JD002687, 2003.

Haywood, J. M., Allan, R. P., Culverwell, I., Slingo, T., Milton, S., Edwards, J., and Clerbaux, N.: Can desert dust explain the outgoing longwave radiation anomaly over the Sahara during July 2003?, J. Geophys. Res., 110, D05105, doi:10.1029/2004JD005232, 2005.

Haywood, J. M., Pelon, J., Formenti, P., et al.: Overview of the dust and Biomass Burning Experiment and African Monsoon Multidisciplinary Analysis Special Observing Period-0, J. Geophys. Res., 113, D00C17, doi:10.1029/2008JD010077, 2008.

Heinold, B., Tegen, I., Esselborn, M., et al.: Regional Saharan dust modelling during the SAMUM 2006 campaign. Tellus, 61B, 307-324, doi:10.1111/j.1600-0889.2008.00387, 2009.

Helmert, J., Heinold, B., Tegen, I., Hellmuth, O., and Wendisch, M.: On the direct and semidirect effects of Saharan dust over Europe: A modeling study, J. Geophys. Res., 112, D13208, doi:10.1029/2006JD007444, 2007.

Hess, M., Koepke, P., and Schult, I.: Optical properties of aerosols and clouds: The software package, B. Am. Meteorol. Soc., 79, 831-844, 1998.

Huebert, B. J., Bates, T., Russell, P. B., Shi, G., Kim, Y. J., Kawamura, K., Carmichael, G., and Nakajima, T.: An overview of Ace-Asia: Strategies for quantifying the relationships between 
Asian aerosols and their climatic impacts, J. Geophys. Res., 108(D23), 8633, doi:10.1029/2003JD003550, 2003.

Jiang, H. and Feingold, G.: Effect of aerosol on warm convective clouds: Aerosol-cloud-surface flux feedbacks in a new coupled large eddy model, J. Geophys. Res., 111, D01202, doi:10.1029/2005JD006138, 2006.

Kim, S.-W., Yoon, S.-C., Jefferson, A., et al.: Observation of enhanced water vapour in Asian dust layer and its effect on atmospheric radiative heating rates, Geophys. Res. Lett., 31, L18113, doi:10.1029/2004GL020024, 2004.

Koepke, P., Hess, M., Schult, I., and Shettle, E. P.: Global Aerosol Data Set, MPI Meteorologie Hamburg, Report No. 243, 44pp., 1997.

Konaré, A., Zakey, A. S., Solmon, F., Giorgi, F., Rauscher, S., Ibrah, $\mathrm{S}$., and $\mathrm{Bi}, \mathrm{X}$.: A regional climate modeling study of the effect of desert dust on the West African monsoon, J. Geophys. Res., 113, D12206, doi:10.1029/2007JD009322, 2008.

Lafon, S., Sokolik, I. N., Rajot, J. L., Caquineau, S., and Gaudichet, A.: Characterization of iron oxides in mineral dust aerosols: Implications for light absorption, J. Geophys. Res., 111, D21207, doi:10.1029/2005JD007016, 2006.

Lafore, J., Stein, J., Asencio, N., et al.: The Meso-NH atmospheric simulation system, Part I: Adiabatic formulation and control simulations, Ann. Geophys., 16, 90-109, 1998, http://www.ann-geophys.net/16/90/1998/.

Lau, K.-M. and Kim, K.-M.: Observational relationships between aerosol and Asian monsoon rainfall, and circulation, Geophys. Res. Lett., 33, L21810, doi:10.1029/2006GL027546, 2006.

Lelieveld, J., Berresheim, H., Borrmann, S., et al.: Global Air Pollution Crossroads over the Mediterranean, Science, 298, 794, 2002.

Lio, H. and Seinfeld, J. H.: Radiative forcing by mineral dust aerosols: sensitivity to key variables, J. Geophys. Res., 103(D24), 31637-31645, 1998.

Mallet, M., Pont, V., Liousse, C., et al.: Aerosol direct radiative forcing over Djougou (northern Benin) during the African Monsoon Multidisciplinary Analysis dry season experiment (Special Observation Period-0), J. Geophys. Res., 113, D00C01, doi:10.1029/2007JD009419, 2008.

McFarlane, S. A., Kassianov, E. I., Barnard, J., et al.: Surface shortwave aerosol radiative forcing during the Atmospheric Radiation Measurement Mobile Facility deployment in Niamey, Niger, J. Geophys. Res., 114, D00E06, doi:10.1029/2008JD010491, 2009.

Marticorena, B., Bergametti, G., Aumont, B., Callot, Y., N'Doumé, C., and Legrand, M.: Modeling the atmospheric dust cycle: 2Simulation of Saharan sources, J. Geophys. Res., 102, 43874404, 1997.

McConnell, C. L., Highwood, E. J., Coe, H., et al.: Seasonal variations of the physical and optical characteristics of Saharan dust: results from the Dust Outflow and Deposition to the Ocean (DODO) Experiment, J. Geophys. Res., 113, D14S05, doi:10.1029/2007JD009606, 2008.

Miller, R. L. and Tegen, I.: Climate response to soil dust aerosols, J. Climate, 11, 3247-3267, 1998.

Miller, R. L., Tegen, I., and Perlwitz, J.: Surface radiative forcing by soil dust aerosols and the hydrologic cycle, J. Geophys. Res., 109, D04203, doi:10.1029/2003JD004085, 2004.

Miller, R. L., Slingo, A., Barnard, J. C., and Kassianov, E.: Seasonal contrast in the surface energy balance of the Sahel, J. Geophys.
Res., 114, D00E05, doi:10.1029/2008JD010521, 2009.

Milton, S. F., Greed, G., Brooks, M. E., Haywood, J., Johnson, B., Allan, R. P., Slingo, A., and Grey, M. F.: Modeled and observed atmospheric radiation balance during the West African dry season: Role of mineral dust, biomass burning aerosol, and surface albedo, J. Geophys. Res., 113, D00C02, doi:10.1029/2007JD009741, 2008.

Mishchenko, M. I., Lacis, A. A., Carlson, B. E., and Travis, L. D.: Nonsphericity of dust-like tropospheric aerosols: Implications for aerosol remote sensing and climate modeling, Geophys. Res. Lett., 22, 1077-1080, 1995.

Mohalfi, S., Bedi, H. S., Krishnamurti, T. N., and Cocke, S. D.: Impact of Shortwave Effects on the Summer Season Heat Low over Saudi Arabia, Monthly Weather Review, 126, 3153-3168, 1998.

Morcrette, J. and Fouquart, Y.: The overlapping of cloud layers in shortwave radiation parameterizations, J. Atmos. Sci., 43(4), 321-328, 1986.

Myhre, G. and Stordal, F.: Global sensitivity experiments of the radiative forcing due to mineral aerosols, J. Geophys. Res., 106(D16), 18193-18204, 2001.

Osborne, S. R., Johnson, B. T., Haywood, J. M., Baran, A. J., Harrison, M. A. J., and McConnell, C. L.: Physical and optical properties of mineral dust aerosol during the Dust and Biomass-burning Experiment, J. Geophys. Res., 113, D00C03, doi:10.1029/2007JD009551, 2008.

Otto, S., Bierwirth, E., Weinzierl, B., et al.: Solar radiative effects of a Saharan dust plume observed during SAMUM assuming spheroidal model particles, Tellus, 61B, 270-296, doi:10.1111/j.1600-0889.2008.00389, 2009.

Pelon, J., Mallet, M., Mariscal, A., et al.: Microlidar observations of biomass burning aerosol over Djougou (Benin) during African Monsoon Multidisciplinary Analysis Special Observation Period 0: Dust and Biomass-Burning Experiment, J. Geophys. Res., 113, D00C18, doi:10.1029/2008JD009976, 2008.

Prospero, J. M. and Lamb, P. J.: African droughts and dust transport to the Caribbean: Climate change implications, Science, 302, 1024-1027, 2003.

Ramanathan, V., Crutzen, P. J., Lelieveld, J., et al.: Indian Ocean Experiment, An integrated analysis of the climate forcing and effects of the great Indo-Asian haze, J. Geophys. Res., 106(D22), 28371-28398, 2001.

Ramanathan , V., Li, F., Ramana, M. V., et al.: Atmospheric brown clouds: Hemispherical and regional variations in longrange transport, absorption, and radiative forcing, J. Geophys. Res., 112, D22S21, doi:10.1029/2006JD008124, 2007.

Redelsperger, J., Thorncroft, D., Diedhiou, A., Lebel, T., Parker, D., and Polcher, J.: African monsoon multiplidisciplinary analysis: An international research project and field campaign, B. Am. Meteorol. Soc., 87, 1739-1746, 2006.

Slingo, A., Ackerman, T. P., Allan, R. P., et al.: Observations of the impact of a major Saharan dust storm on the atmospheric radiation balance, Geophys. Res. Lett., 33, L24817, doi:10.1029/2006GL027869, 2006.

Solmon, F., Mallet, M., Elguindi, N., Giorgi, F., Zakey, A., and Konaré, A.: Dust aerosol impact on regional precipitation over western Africa, mechanisms and sensitivity to absorption properties, Geophys. Res. Lett., 35, L24705, doi:10.1029/2008GL035900, 2008. 
Sinyuk, A., Dubovik, O., Holben, B., et al.: Simultaneous retrieval of aerosol and surface properties from a combinaison of AERONET and satellite data, Remote Sens. Environ., 107, 90-108, 2007.

Tanré, D., Haywood, J. M., Pelon, J., Léon, J. F., Chatenet, B., Formenti, P., Francis, P., Goloub, P., Highwood, E. J., and Myhre, G.: Measurements and modelling of the Saharan dust radiative impact: Overview of the Saharan Dust Experiment (SHADE), J. Geophys. Res., 108(D18), 8574, doi:10.1029/2002JD003273, 2003.

Tegen, I. and Lacis, A. A.: Modeling of particle size distribution and its influence on the radiative properties of mineral dust aerosol, J. Geophys. Res., 101(D14), 19237-19244, 1996.

Tulet, P., Crassier, V., Cousin, F., Suhre, K., and Rosset, R.: ORILAM, a three-moment lognormal aerosol scheme for mesoscale atmospheric model: Online coupling into the MesoNH-C model and validation on the Escompte campaign, J. Geophys. Res., 110, D18201, doi:10.1029/2004JD005716, 2005.
Tulet, P., Mallet, M., Pont, V., Pelon, J., and Boon, A.: The 713 March 2006 dust storm over West Africa: Generation, transport, and vertical stratification, J. Geophys. Res., 113, D00C08, doi:10.1029/2008JD009871, 2008.

Wendisch, M., Hellmuth, O., Ansmann, A., et al.: Radiative and dynamic effects of absorbing aerosol particles over the Pearl River Delta, China, Atmos. Environ., 42, 6408-6416, 2008.

Woodward, S.: Modeling the atmospheric life-cycle and radiative impact of mineral dust in the Hadley Centre climate model, J. Geophys. Res., 106, 18155-18166, 2001.

Yoshioka, M., Mahowald, N. M., Conley, A. J., et al.: Impact of Desert Radiative Forcing on Sahel Precipitation : Relative Importance of Dust Compared to Sea Surface Temperature Variations, Vegetation Changes, and Greenhouse Gas Warming, J. Climate, 20, 1445-1467, doi:10.1175/JCLI4056.1, 2007. 